\title{
Advances in quantifying soil organic carbon under different land uses in Ethiopia: a review and synthesis
}

\author{
Chukwuebuka C. Okolo ${ }^{1,2^{*}}$ (D), Girmay Gebresamuel ${ }^{1}$, Abeba N. Retta ${ }^{1}$, Amanuel Zenebe ${ }^{1,2}$ and Mitiku Haile ${ }^{1}$
}

\begin{abstract}
Background: In the face of climate change and global warming, scientists globally are striving for effective techniques on how best to sequester carbon in order to reduce global warming and achieve environmental sustainability. This paper reviews the available literature on the influence of various land use changes on gains and/ or losses of soil carbon (C) stocks in Ethiopia.

Results: Our review indicated that 33.3\% of the studies reported soil organic carbon (SOC) concentration, 13.9\% reported only SOC stock while $52.8 \%$ reported both SOC concentration and stock. Studies focusing on 0-30 cm only were $44 \%$, other studies extending up to 40 to $100 \mathrm{~cm}$ were $50 \%$, and studies extending to more than $100 \mathrm{~cm}$ accounted for $2.8 \%$ while studies without any depth specification accounted for $2.8 \%$. Irrespective of soil type, C stocks in the top soil $(0-30 \mathrm{~cm})$ were found to be higher than at subsoil depths. Even though there is significant improvement in $\mathrm{C}$ sequestration in exclosures and community forests, the level of $\mathrm{C}$ sequestered is still below that of church forests.

Conclusion: Conversion of native forest to other land uses resulted in a significant decrease in the SOC stocks across Ethiopia. Absence of long-term field trials and non-existence of SOC database are among the major drawbacks of SOC studies in Ethiopia identified in this review. With better management practices, it is possible to restore depleted $C$ concentrations and stocks even in degraded lands and to conserve $C$ in more pristine lands across the rugged landscapes of Ethiopia.
\end{abstract}

Keywords: Agroecosystem, Climate change, Carbon sequestration, Land degradation, Luvisols, Resilience, Vertisols

\section{Introduction}

Rapid deforestation and degradation of forest resources remains a major problem in Ethiopia were effects of climate change (for example increase in average temperature, and variability in rainfall pattern) is highly being experienced and according to World Bank (2010), Ethiopia remains one of the countries most vulnerable to climate change. More so, the rugged landscapes of Ethiopia, especially northern Ethiopia have witnessed unprecedented degradation occasioned by agricultural intensification and land misuse for the past three millennia (Nyssen et al. 2015). Recently, the trend is gradually changing with concerted efforts by concerned stakeholders (local communities, non-governmental

\footnotetext{
* Correspondence: okolochukwuebuka@gmail.com

'Department of Land Resources Management and Environmental Protection, Mekelle University, P.O. Box 231, Mekelle, Ethiopia

${ }^{2}$ Institute of Climate and Society, Mekelle University, Mekelle, Ethiopia
}

organizations (NGO's), concerned individuals, and organized environmental groups) to ensure total restoration of degraded landscapes in most regions of Ethiopia through sustainable approaches. Different land uses and soil management practices have variable contributions toward the nature, quality, and quantity of carbon $(\mathrm{C})$ storage and/or $\mathrm{CO}_{2}$ emission. The potential of soil to sequester carbon cannot be over-emphasized, and with approximately 2344 gigatone $(\mathrm{Gt})$ (1 gigatone $=1$ billion tones) of global organic carbon storage (Lal 2004a), making soil the largest terrestrial pool of organic carbon (Stockmann et al. 2013). To soil depths of $30 \mathrm{~cm}$ and $1 \mathrm{~m}$, the global stock of soil organic carbon (SOC) has been estimated to be in the range of 684-724 Pg and 14621548 Pg respectively (Batjes 1996).

Thus, the soil is a potential natural sink for $C$ because of being the largest terrestrial pool of SOC in addition 
to the relatively long residence time of organic $\mathrm{C}$ in the soil (Batjes 2001). In the $0-30 \mathrm{~cm}$ topsoil layer, the quantity of SOC is approximately twice the amount of $\mathrm{C}$ in atmospheric carbon dioxide $\left(\mathrm{CO}_{2}\right)$ and three times that in aboveground vegetation globally (Batjes 2001; Lal 2004a, 2004b). Across different regions in the world, the SOC concentration ranges from low to high in soils of arid and temperate regions respectively and extremely high in organic or peat soils (Lal 2004a, 2004b). Annual release of $\mathrm{CO}_{2}$ from deforestation as estimated in the Fourth Assessment Report (AR4) of the Intergovernmental Panel on Climate Change (IPCC) is approximately 25\% of $\mathrm{CO}_{2}$ released from fossil fuel burning (IPCC 2007; Powlson et al. 2011). Depletion of SOC pool has led to estimated loss of $78 \pm 12 \mathrm{Pg} \mathrm{C}$ to the atmosphere (Lal 2004a). Ruddiman (2003) as reported in Lal et al. (2012) estimated that the total emission of $\mathrm{CO}_{2}$ from the terrestrial biosphere is equivalent to $427 \mathrm{Pg}$ considering emissions of $\mathrm{CO}_{2}-\mathrm{C}$ over 800 years. In addition to emission from land use conversion with emphasis on the period of pre-industrial era to 2010, WMO (2010) reported that total anthropogenic emissions have increased atmospheric concentration of $\mathrm{CO}_{2}$ from 280 to $390 \mathrm{ppm}$. Lal (2004a) estimated that soils under cultivation have lost approximately one-half to two-thirds of the native SOC pool in addition to cumulative loss of $30-40 \mathrm{Mg} \mathrm{C} / \mathrm{ha}$. It is well documented in the literature that soil $\mathrm{C}$ depletion is aggravated by soil degradation and worsened by soil mismanagement and land misuse (Lal 2002; Lal 2004a, 2004b; Powlson et al. 2011; Stockmann et al. 2013) predisposing the soil as a source of $\mathrm{C}$ emission. It is noteworthy that with the exception of Histosols having 13-27\% soil organic matter (by weight) (SSSA 2001), tropical soils of Sub-Saharan Africa, and temperate soils of Europe/America has documented average soil organic matter content ranging between $0.5-3.0$ and $10-13 \%$ soil organic matter respectively (Stockmann et al. 2013).

Recently in Ethiopia within the last few decades, concerted efforts by the local communities has been observed with regards to enthroning sustainable land management practices, for example establishment of exclosures geared toward restoration of degraded lands. Nyssen et al. (2015) systematically addressed the historical and future events of land resources management in Africa with emphasis on semi-arid area of northern Ethiopia. Their investigation revealed gradual decrease in gully erosion since around 2000, thus corresponding to enhanced and improved conservation practices in addition to enriched vegetative cover unlike the 1960s, when strong gully channel incision phase commenced.

Previous authors (Girmay et al. 2008; Shiferaw et al. 2013) have made appreciable efforts to review and synthesize studies of soil carbon stocks in Ethiopia with respect to land use, soil management practices, and climate mitigation, but with a focus at regional and selected areas of the country, which is a major gap this review intends to fill. Owing to disparity and dearth of available information in literature, our review reported both soil $\mathrm{C}$ concentrations and stocks reported in various studies in Ethiopia up to 2018 to represent the SOC pool.

This review intends to summarize and synthesize available literatures (past and present research findings) on soil carbon sequestration (viz-a-viz $\mathrm{C}$ concentration and stock) in the tropics with special focus on Ethiopia. Findings of this review will form the integral basis for improved policy formulation and concerted efforts toward ensuring sustainable land use and $\mathrm{C}$ storage across different landscapes in tropical agroecosystems. This review will thus form the foundation for the national soil database carbon pools estimate, which currently does not exist in Ethiopia. Most importantly, key findings of this review will be useful to land managers, agriculturists, environmentalists, and policy makers, in view of ensuring better soil management strategies geared towards increasing SOC quantity, quality, and stability in degraded soils of Ethiopia.

\section{Methodology}

For the purpose of this review, we reported both soil organic $\mathrm{C}$ concentration and stock to represent SOC pool. The methodological approach adopted was literature search, which was carried out using the following search engines and platforms: Web of Science (apps.webofknowledge.com), Research Gate (https:// www.researchgate.net), Google Scholar (scholar.google.com), AGRIS (agris.fao.org), and Science Direct (http://www.sciencedirect.com). Related $\mathrm{PhD}$ and MSc theses and dissertations (unpublished) sourced from different university archives were also used for this review. Literatures published up to 2018 were used as the benchmark, while "soil carbon sequestration under different land uses and climate change mitigation" were uses as key words. More than 1000 papers were retrieved from the different search engines, but emphasis was laid on the papers with research findings focusing on Ethiopia. Individual articles from the collected literature were grouped with respect to research objectives and experimental types. Articles with replicated studies focusing on soil organic carbon concentration and stock in Ethiopia under different land uses, options for increasing soil carbon sequestration, and analytical methods for soil carbon determination formed the basis of sub-categorizing the research objectives. Soil 
organic carbon concentration and soil organic carbon stock are both reported in this review to represent soil organic carbon pool. In some places, SOC and soil organic matter (SOM) are used interchangeably. Our emphasis was only on SOC studies, thus articles on soil inorganic carbon (SIC) were not included in this review. Figure 1 indicates the different locations of the studies in Ethiopia cited in this review, Fig. 2 shows the land use cover map of Ethiopia while Appendix 1 presents the data of referred articles used in calculations.

The major land uses reported in the literature include natural forest, agroforestry, church forest, controlled grazing, open communal grazing, rainfed crop production, irrigation-based crop production, agroforestry, silvopasture, irrigation-based fruit production, exclosure, and grassland. Analytical methods used in all the reported studies varies, and included wet (Walkley and Black 1934) and dry (dichromate) combustion method, isotope ratio mass spectrometer, infra-red spectroscopy, and reflectance spectrometer for SOC determination (see Table 1). The core sampling technique was used in all articles for bulk density determination from undisturbed soil core samples for calculating SOC stock. Reported data were those showing (i) total SOC concentration and (ii) stocks (mass/area for a specific soil depth basis, for different land use types (see Table 2). Preparation of soil sample in all reported studies adopted removal of organic layers prior to sample collection, air-drying for at least 2-3 weeks, removal of coarse fragments/roots and debris, and sieving with $<2 \mathrm{~mm}$ sieve. Dominant soil type in reported studies according to World Reference Base for soil resources (WRB 2006) were mainly Lithosols, Nitosols, Cambisols, Regosols, Arenosols, and association of Arenosols with Regosols, Vertisols, and Leptosols. Due to differences in sampling depths in reported studies, data were grouped into two standard depth intervals $(0-30 \mathrm{~cm}$ for top soil) and $30-100 \mathrm{~cm}$ for deep soil)

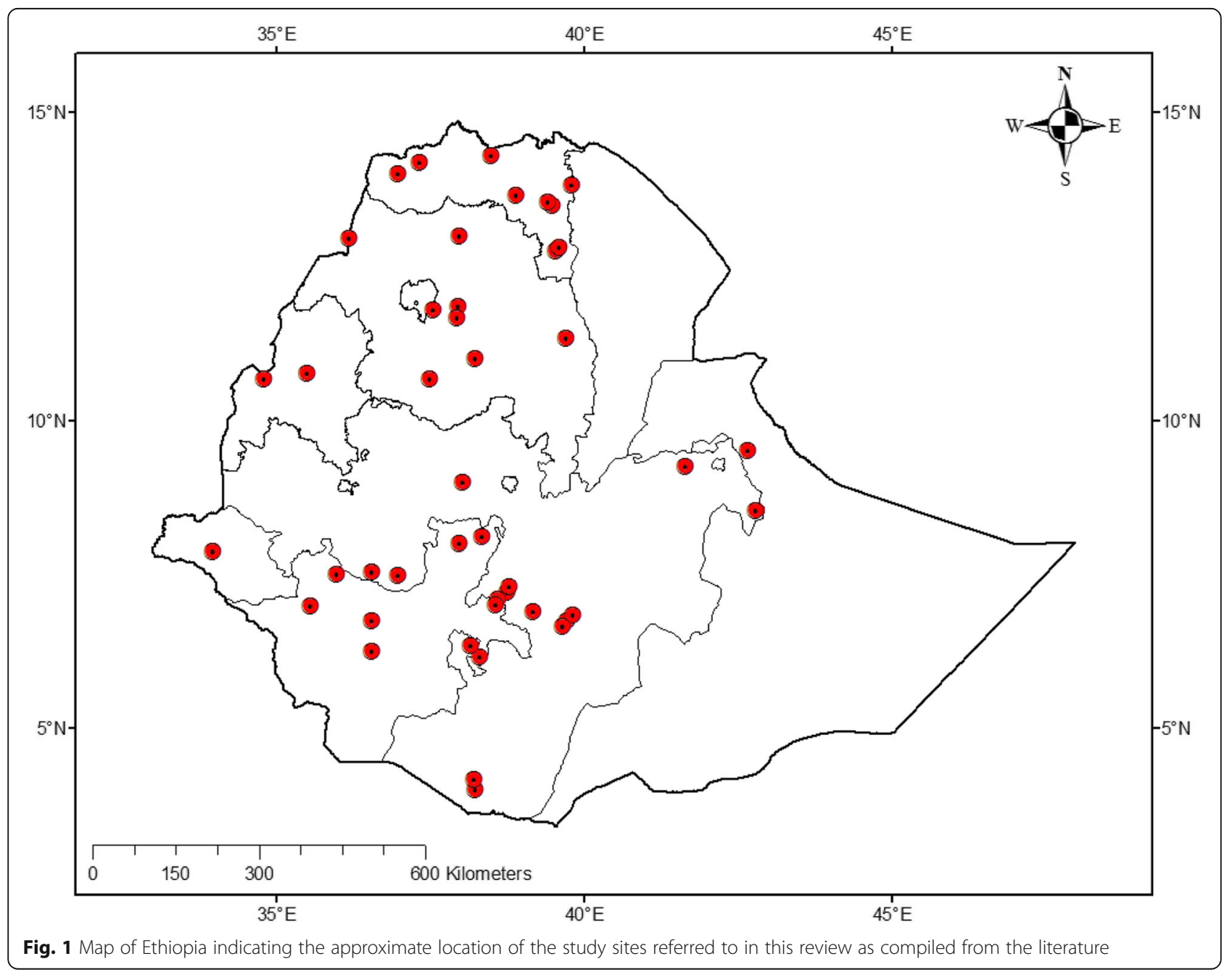




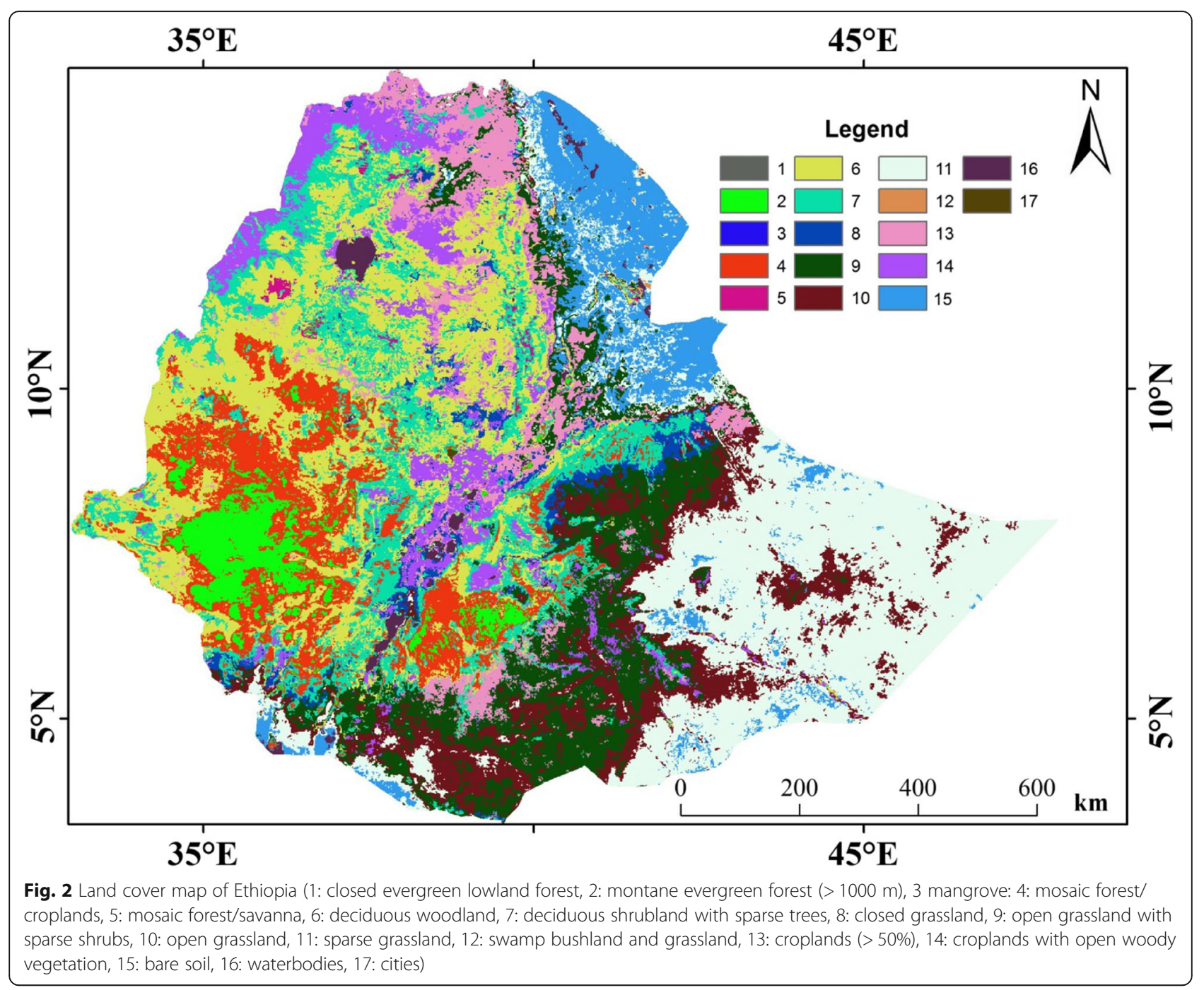

Table 1 Different methods of soil carbon determination used in referred authors

\begin{tabular}{|c|c|c|}
\hline Methods* & Number of observations & Percentage proportion (\%) \\
\hline \multicolumn{3}{|l|}{ Ex-situ methods: } \\
\hline $\begin{array}{l}\text { 1. Walkley and Black Method } \\
\text { (Wet oxidation or combustion) }\end{array}$ & 21 & $58.2 \%$ \\
\hline 2. Dry combustion method: $\mathrm{CN}$ analyser & 9 & $25 \%$ \\
\hline 3. Dry combustion: weight-loss-on-ignition & 2 & $5.6 \%$ \\
\hline \multicolumn{3}{|l|}{ In-situ methods (in combination with Ex-situ methods): } \\
\hline 4. Isotope ratio mass spectrometer & 1 & $2.8 \%$ \\
\hline $\begin{array}{l}\text { 5. Dry combustion coupled Infra-red spectroscopy } \\
\text { Isotope mass spectrometer }\end{array}$ & 2 & $5.6 \%$ \\
\hline $\begin{array}{l}\text { 6. Walkley and Black Method coupled } \\
\text { Reflectance spectrometer }\end{array}$ & 1 & $2.8 \%$ \\
\hline Total & 36 & 100 \\
\hline
\end{tabular}


Table 2 Soil organic carbon pools and different units reported by referred authors

\begin{tabular}{|c|c|c|}
\hline Soil organic carbon pool* & Number of observations & Percentage proportion (\%) \\
\hline 1. Soil carbon concentration $(\mathrm{g} / \mathrm{kg})$ & 3 & $8.3 \%$ \\
\hline 2. Soil carbon concentration (\%) & 9 & $25 \%$ \\
\hline Soil carbon concentration & & $33.3 \%$ \\
\hline 3. Soil carbon stock (Mg/ha) & 3 & $8.3 \%$ \\
\hline 4. Soil carbon stock $\left(\mathrm{kg} \mathrm{m}^{-2}\right)$ & 1 & $2.8 \%$ \\
\hline 5. Soil carbon stock (t/ha) & 1 & $2.8 \%$ \\
\hline Soil carbon stock & & $13.9 \%$ \\
\hline 6. Soil carbon concentration (g/kg) and Soil carbon stock (Mg/ha) & 6 & $16.7 \%$ \\
\hline 7. Soil carbon concentration (\%) and Soil carbon stock (Mg/ha) & 8 & $22.2 \%$ \\
\hline 8. Soil carbon concentration (\%) and Soil carbon stock (t/ha) & 3 & $8.3 \%$ \\
\hline 9. Soil carbon concentration $(\mathrm{g} / \mathrm{kg})$ and Soil carbon stock $\left(\mathrm{g} \mathrm{m}^{-2}\right)$ & 1 & $2.8 \%$ \\
\hline 10. Soil carbon concentration (\%) and Soil carbon stock $\left(\mathrm{g} \mathrm{m}^{-2}\right)$ & 1 & $2.8 \%$ \\
\hline Soil carbon concentration and Carbon stock & & $52.8 \%$ \\
\hline Total & 36 & 100 \\
\hline
\end{tabular}

*See Appendix 1 for details

to ensure comparability in reporting trend distribution. All articles reporting data for individual depths (e.g., $0-5,5-15,15-30 \mathrm{~cm}$ ) were summed and included in standardized grouping of $0-30 \mathrm{~cm}$ depth while articles reporting data above $30 \mathrm{~cm}$ were included in $30-100 \mathrm{~cm}$ depth interval.

\section{Uncertainties in soil organic carbon studies}

Certain level of uncertainty still exist with respect to the relative amount of stored SOC under different land uses and agroecosystems across different landscapes of Ethiopia, SOC distribution and dynamics across soil profile, and its relative comparison (quantity, quality, and elemental composition) across vegetative covers under varying seasons and temperature regimes. Soil $\mathrm{C}$ change quantification in the soil is quite a challenging task and more specific emphasis should be paid to the extent of $\mathrm{C}$ stock below the topsoil $(0-30 \mathrm{~cm})$ zone. With focus on Sub-Saharan Africa in a systematic review, Vågen et al. (2005) advocated for further detailed investigative studies across different agroecosystems for clear understanding on $\mathrm{C}$ dynamics and behavior as an impact of land cover intensities. The general welfare coupled with the socioeconomic benefits of soil carbon sequestration (SCS) in African countries ought to be propagated in order to enlighten the local populace and equally stimulate them on the need to embrace best management practices to sequester carbon. The diversity in climate, geology, and topography of the country (Ethiopia) has given rise to a wide range of heterogeneity of soil types (Mesfin 1988; Haileslassie et al. 2005; Hurni et al. 2007). Thus, there is clear need for country-based and region-specific articulated studies to address the issues of accurate quantification and measurement of SOC especially below the subsoil zone under changing climate in Ethiopia.

Contrast to previous researchers, Powlson et al. (2011) and Stockmann et al. (2013) argued that increased levels of SOC with the adoption different approaches and management practices does not literally translate to capture or allocation of extra $\mathrm{C}$ from the atmosphere to land. However, this might just be due to ordinary movement of $\mathrm{C}$ within the biosphere from one pool to another, without any negative or positive consequences for climate change. This implies that not all findings reporting increased SOC in land uses under different management practices are actually $C$ capture from the atmosphere. Powlson et al. (2008) further recommended the term "accumulation" to represent increases in SOC while "sequestration" should be specifically used for scenarios and circumstances of significant extra transfer or capture of $\mathrm{C}$ from the atmosphere, which represents a valid approach to mitigating climate change. Thus, this assertion needs to be critically examined by researchers in view of providing a clear mechanistic understanding of SOC sequestration and dynamics in the face of climate change.

Site-specific conditions, soil types, and dynamic nature of environmental-dependent variables $(\mathrm{pH}$, temperature, precipitation, and various anthropogenic activities) were potential sources of variations in the reported SOC pool. More so, differences in analytical methods employed by the researchers equally accounts for variations in the trend of $\mathrm{C}$ pool reported in this review (see Table 1). Detailed 
overview of different techniques employed in modern times for SOC determination is well presented by Chatterjee et al. (2009).

Despite the wide usage of the "traditional" Walkley and Black (WB) method, due to its procedural simplicity (Wang et al. 2012), it has been heavily criticized due to its limitations, which include incomplete combustion, variations in oxidation of various forms of SOC by dichromate, high cost of chemicals used for the analysis, and considerable low efficiency in C determination (FAO 2001, 2007; Gelman et al. 2012; Amare et al. 2013; Gebeyehu et al. 2017). Nevertheless, more accurate, precise, and cost-effective measurement of SOC is required in $\mathrm{C}$ sequestration programs in terrestrial ecosystems in view of ensuring accurate quantification, verification, and monitoring of potential SOC stocks over time. Despite the acclaimed efficiency of dry combustion auto-analyzers, it is also associated with some levels of instrumental and measurement errors (Aynekulu et al. 2011; Batjes 2011). Estimated 1-2\% measurement errors have been associated with SOC laboratory analysis determination using dry combustion auto-analyzers (FAO 2001). In-situ analytical methods, e.g., near-infrared spectroscopy (NIR) and mid-infrared spectroscopy (MIR), have been developed as a more reliable, efficient, and high precision method of SOC determination across landscapes using efficient sampling methodologies (Stockmann et al. 2013). A systematic combination of these analytical methods is relatively cheaper and cost-effective compared to the widely used "traditional" methods (Janik et al. 2007; Stockmann et al. 2013) with a higher degree of precision and accuracy.

Recently, Gessesse and Khamzina (2018) studied the reliability of WB method in analyzing $\mathrm{C}$ poor soils of semi-arid area of Ethiopia in comparison with elemental $\mathrm{CN}$ analyzer. Their findings showed that results obtained by WB method had a closer similarity with those obtained from $\mathrm{CN}$ elemental analyzer, using the Bland and Altman analysis. In conclusion, they proposed the use of 1.32 standard correction factor for SOC evaluation using the WB method in C-poor non-calcareous soils of semi-arid area of Ethiopia and tropical regions of sub-Saharan Africa.

\section{Past and present scientific evidence of soil organic carbon distribution in Ethiopia}

Ethiopia is strategically located in the horn of Africa $\left(2^{\circ} 54^{\prime} \mathrm{N}-15^{\circ} 18^{\prime} \mathrm{N}\right.$ latitude and $32^{\circ} 42^{\prime} \mathrm{E}-48^{\circ} 18^{\prime}$ E longitude), though a land-locked country but with massive land area of 1.12 million $\mathrm{km}^{2}$ (Shiferaw et al. 2013), coupled with diverse climate, parent material, land use, geology, and topography giving rise to a wide heterogeneity of soil types (Hurni et al. 2007; Mesfin 1988; Haileslassie et al. 2005). According to FAO (1986) as reported in Haileslassie et al. (2005), soils of Ethiopia are mainly of volcanic origin and Lithosols (14.7\%), Nitosols (13.5\%), Cambisols (11.1\%), Regosols (12\%), and Vertisols (10.5\%) proportionally cover the country's vast area of landmass.

The potential of soil organic carbon (SOC) to act as a "managed" sink and reservoir for atmospheric $\mathrm{CO}_{2}$ has received considerable attention in scientific literatures (Kirschbaum 2000; Post and kwon 2000; NMSA 2001; Guo and Gifford 2002; Lal 2004a, 2004b; Post et al. 2004; Lemenih and Itanna 2004; Lal 2008a, 2008b, 2008c; Smith 2008; Chabbi and Rumpel 2009; Post et al. 2009; Anikwe 2010; Luo et al. 2010; Niles et al. 2010; Nwite and Okolo 2017; Mbah et al. 2017; Okebalama et al. 2017). Significant increase in greenhouse gas (GHG) emissions in Ethiopia has been reported (NMSA 2001) while the sink capacity in agriculture, forestry, and land use sectors are rapidly decreasing, according to the first national GHG inventory carried out in 1994 (Shiferaw et al. 2013).

There exist several published scientific articles and case studies on soil carbon pools for different parts of Ethiopia (Yimer et al. 2006; Girmay et al. 2008; Hawando 1997; Solomon et al. 2002a; Lemenih et al. 2005; Haileslassie et al. 2005; Lemma et al. 2006; Edwards 2007; Chibsa and Ta 2009; Freier et al. 2009; Fisseha et al. 2011; Kim et al. 2015; Demessie et al. 2015; Berihu et al. 2017) but with a missing gap on the national soil database carbon pools estimate (Shiferaw et al. 2013; Okolo et al. 2016). However, most of the SOC researches were conducted in the southern part of Ethiopia, thus not giving a comprehensive clear overview of the trend in total soil carbon distribution data across different landscapes and regions of Ethiopia, which this review intends to address systematically. For example in the highlands of southern Ethiopia, changes in SOC stock was investigated by Lemenih et al. (2005) after reforestation of previously cultivated soil in comparison with continuously cultivated soils and adjacent natural forests soils. For Cupressus lusitanica and Eucalyptus saligna, they reported an average annual soil $\mathrm{C}$ accumulation estimate of 156 and $37 \mathrm{~g} \mathrm{C} \mathrm{m}^{-2}$ year $^{-1}$ respectively. Their study, which focused on $0-10$, $10-20,20-40,40-60$, and $60-80 \mathrm{~cm}$, further revealed that reforestation of previous croplands lead to restoration of lost $\mathrm{C}$, even though the differences in deep soils (below $20 \mathrm{~cm}$ ) were not significant. However, significant difference in soil $\mathrm{C}$ was 
observed in topsoil $(0-10$ and $10-20 \mathrm{~cm})$ layers in the following order: Natural forest $>C$. lusitanica $>$ E. saligna $>$ Farmland. Similarly, Negasa et al. (2017) studied variations in soil properties under different land use types along a toposequence in smallholder-managed farms in southern Ethiopia. Their study focused on three land use types (agroforestry land, cultivated land, and grazing land), three slope categories (upper, middle, and lower slope), and four soil depths: 0-20 cm, 20-40 cm, $40-60 \mathrm{~cm}$, and $>60 \mathrm{~cm}$. However, $\mathrm{SOC}$ showed significant variation among land use types especially in top soil layers while Agroforestry land use type had higher SOC content and the least SOC content was recorded in cultivated land. Their results indicated that SOC content decreased down the slope and the low SOC in cultivated land was attributed to continuous tillage practices by the local smallholder farmers.

In exploring the magnitude of land degradation, estimated soil organic matter (SOM) loss of 1.17$78 \mathrm{Tg}_{\text {year }}{ }^{-1}$ from $78 \mathrm{M}$ ha of cultivated and grazing lands was reported by Demessie et al. (2015) in southern Ethiopia. They reported high soil quality index for natural forest and Juniperous procera, and advocated for protection of natural forests from additional accelerated degradation and conversion to other land uses. Increase in SOC storage and decrease in $\mathrm{CO}_{2}$ emission can be achieved with afforestation and sustainable measures geared towards safe-guarding remnants of the forests. In Gambo district in southern Ethiopia, Demessie et al. (2011, 2012) compared the SOC trend among six plantation species with natural forest and reported higher SOC concentration in the 0 to $10 \mathrm{~cm}$ depth, which progressively decreased to the $100 \mathrm{~cm}$ depth across all land uses. The concentration of SOC varied from 3.4 to $10.2 \%$ in soils under plantations and natural forest. Juniperous procera in addition to the natural forest accrued more SOC across depths compared to other plantations (Eucalyptus globulus, Eucalyptus saligna, Eucalyptus camaldulensis, Cupressus lusitanica, and Pinus patula).

More so, Singh et al. (2010) in a study to assess the status of SOC and the rate of change in the chronosequences in southeastern Ethiopia reported that higher amount of SOC was concentrated in the topsoil $(0$ to $20 \mathrm{~cm})$ and the concentration $\mathrm{SOC}$ in natural forest was significantly higher than that in agroforestry and agricultural lands. Singh et al. (2010) equally reported similar trend in a study to evaluate soil carbon sequestration under chronosequences of agroforestry and cultivated lands in southern Ethiopia. Specifically, SOC stocks in all chronosequences $(12,20,30,40$, and 50 years) of traditional agroforestry were higher than the corresponding chronosequences under agricultural lands.

Lemma et al. (2006) in a study at Belete forest in southeastern Ethiopia used total carbon and ${ }^{13} \mathrm{C}$ analyses to assess the changes in SOC pools in relation to changes in land use. They reported apparent SOC accumulation rates of $1-3.2 \mathrm{Mg} \mathrm{ha}^{-1}$ year $^{-1}$ within a space of 20 years following afforestation of an abandoned cultivated land. However, the accumulation rate is dependent on the type of species. Their study reported that continuous cropping following forest clearing gave rise to estimated loss of $43 \%$ (75.4 $\mathrm{Mg} \mathrm{ha}^{-1}$ ) total SOC and 73\% (128.4 $\mathrm{Mg} \mathrm{ha}^{-1}$ ) forest-derived SOC within a timeframe of 75 years. Nevertheless, addition of $53.0 \mathrm{Mg} \mathrm{ha}^{-1}$ of SOC of $\mathrm{C}_{4}$ crop origin (maize) to the farmland resulted in a lower net loss of SOC. Kim et al. (2015) in a study in Wondo Genet, Southern Ethiopia compared SOC and total nitrogen (TN) stocks in seven paired sites of home gardens and converted mono-crop fields following 1 to 20 years after conversion. They however reported 18-30\% SOC loss as a result of the conversion of home garden agroforestry to crop fields. The research findings suggest that decline in soil fertility, water availability, and increases in GHG gases $\left(\mathrm{CO}_{2}\right.$ and $\left.\mathrm{N}_{2} \mathrm{O}\right)$ emissions is aggravated with the unsustainable management practice of conversion of home gardens to mono-crop. Also, in mono-crop fields, no significant relationship was observed between years after conversion and rates of decrease in SOC stock. In the Bale zone of southeastern Ethiopia, Abera and Belachew (2011) studied the effect of land use on SOC in soils from four land use types (forestland, grassland, fallow land, and cultivated land) and reported consistent decrease in SOC with increasing soil depth across all the land use systems. The highest SOC (12.95\%) concentration was recorded in natural forest with the least concentration of $2.56 \%$ from cultivated land, considering the topsoil layer $(0-10 \mathrm{~cm})$ only. There was minimal variation in SOC concentration at lower depths among different land uses, whereas the topsoil showed significant difference in SOC distribution. This is an indication that the topsoil are mostly affected especially in croplands due to low $\mathrm{C}$ input, total (extractive) harvest, improper management practices, and tillage operations.

In a meta-analysis to assess the long-term effect of land management on SOC in Ethiopia, Shiferaw et al. (2015) reported that the trend in SOC distribution across different land uses were crop land (CL), grass land (GL), and forest land (FL) corresponding to $1.7,2.6$, and $2.8 \mathrm{~g} \mathrm{~kg}^{-1}$ respectively. However, the 
variability pattern for $\mathrm{SOC}$ was $\mathrm{FL}>\mathrm{GL}>\mathrm{CL}$, thus the FL recorded the highest $\mathrm{SOC}$ content while the $\mathrm{CL}$ recorded the lowest SOC content. This result agrees with the previous findings of higher SOC storage in natural ecosystems compared with managed ecosystems of continuously cultivated lands (Assefa et al. 2017; Berihu et al. 2017). In reviewing the impact of different soil management practices and land use changes on soil $\mathrm{C}$ stock in Ethiopia, Girmay et al. (2008) showed that land use conversion from forest to crop land, to open grazing, and to plantation lead to decline in $\mathrm{C}$ stock in approximately $0-63 \%, 0-23 \%$, and $17-83 \%$ respectively at the topsoil layer. The authors proposed adoption of land restorative measures as a panacea to increasing SOC pool. With the adoption of restoration measures, the potential of soil $\mathrm{C}$ sequestration ranges from $0.066-2.2 \mathrm{Tg} \mathrm{C}$ year $^{-1}$ and $4.2-10.5 \mathrm{Tg} \mathrm{C}$ year $^{-1}$ on rainfed cultivated land and rangeland respectively. The proposed land restorative measures in the form of establishments of exclosures is widely practiced in Ethiopia at the moment but still faces challenges of recurrent trespassing and population pressure on the very scarce land.

In the Gacheb catchment of the White Nile Basin, southwest Ethiopia, Kassa et al. (2017) investigated the influence of deforestation on selected soil fertility indices, SOC, and nitrogen $(\mathrm{N})$ stocks. The study focused on four depths $(0-20 \mathrm{~cm}, 20-40 \mathrm{~cm}, 40-$ $60 \mathrm{~cm}$, and $60-80 \mathrm{~cm}$ ), three land uses (natural forest, agroforestry, and croplands), and three elevations (high, middle, and low). Their results showed that the forest top soil layer $(0-10 \mathrm{~cm})$ recorded higher SOC concentration compared to other land uses while the loss of SOC as a result of conversion of forest to cropland ranges from $3.3 \mathrm{Mg} \mathrm{ha}^{-1}$ year $^{-1}$ to $8.0 \mathrm{Mg} \mathrm{ha}^{-1}$ year $^{-1}$. Forestland recorded the highest SOC stock followed by agroforestry with the lowest SOC stock in cultivated land. Undisturbed nature of the natural ecosystems may have contributed to the high SOC content unlike the continuous tillage practices in cropland, which depletes SOC content. In the south-eastern highlands of Ethiopia, Yimer et al. (2006) estimated SOC and TN stocks in $0-30 \mathrm{~cm}$ and $30-100 \mathrm{~cm}$ soil layers for three vegetation communities; Schefflera-Hagenia, Hypericum-Erica-Schefflera, and Erica arborea (shrub size), at different topographic aspects. The results obtained indicated significant variation in SOC among the vegetation communities in the top $30 \mathrm{~cm}$ depth. At the $100 \mathrm{~cm}$ depth, the overall mean SOC ranged from 32.67 to $46.03 \mathrm{~kg} \mathrm{C} \mathrm{m}^{-2}$ among the studied vegetation types across different aspects. The study further showed that the topsoil $(30 \mathrm{~cm}$ depth) stores approximately $45 \%$ of the SOC stock thus indicating the ease of losing potentially huge quantity of $\mathrm{CO}_{2}$ to the atmosphere through deforestation of these vegetation and/or conversion of forest lands into grazing and cultivation.

Furthermore, still on the highlands of southeastern Ethiopia, Yimer et al. (2007) studied the impact of changes in land use on SOC concentration in three adjoining land uses: native forest, cultivated land, and grazing land. Their result indicated significant reduction in the original native quantity of SOC in the upper $100 \mathrm{~cm}$ soil layer by $30.9 \%$ as a result of converting native forests into cultivated lands over a period of 15 years. Their findings equally noted that converting native forests to cultivated lands has given rise to significant reduction in the total quantity of SOC stored in the topsoil as a result of low organic matter supply and reduced $C$ turnover in the soil.

In the plateaus of southern Ethiopia, Solomon et al. (2002a) investigated the composition of organic matter in native forest, tea plantations, Podocarpus-dominated natural forest, Cupressus plantations, 25-year cultivated lands (Paleudalf), and 30-year cultivated lands (Palehumults). According to their findings, significant depletion of total SOC (55\% and 63\%) in the surface soils was due to forest clearing and continuous cultivation respectively. Silt-size separates recorded reduced SOM, thus signifying the high susceptibility of silt-associated SOM to changes in land uses in the study area.

Also in southern Ethiopia, Freier et al. (2009) investigated the SOC dynamics as impact of its chemical configuration on Nitisols under Podocarpus falcatus dominated natural forest and Eucalyptus saligna plantation. At $20-30 \mathrm{~cm}$ soil depth, there was a massive change to less negative $\delta^{13} \mathrm{C}$ values, thus signifying a modification from $C_{4}$ savanna to $C_{3}$ forest during the late Holocene. Using compound-specific stable isotope analysis, their measurements indicated significant differences in $\mathrm{C}$ storage among sites. However, explanation for these differences can be fully elucidated with an initial loss of $15-26 \%$ of SOC approximately half a century years ago, as a result of deforestation. More so, in a study of five major soil types (Andosols, Fluvisols, Nitisols, Solonetz, and Vertisols) in the Rift Valley of Ethiopia for comparison of SOC status over a time period, Itanna et al. (2011) reported that in four of the five soils studied, SOC losses amounted to $60-75 \%$ in less than three decades. Comparing the five soil types, their study revealed that SOC content ranked from highest to lowest in the order of Solonetz, Vertisols, Andosols, Nitisols, and Fluvisols. This assertion is however debatable considering the fact that no information was provided for the land use and management practices 
of the different soil types under consideration. Land use and management practices exert profound influence on $\mathrm{C}$ dynamics irrespective of the soil type. It is therefore illogical to conclude on SOC distribution trend of different soil types without providing information on the particular land use or management practice.

Over the last millennia, land degradation due to changes in land-uses, unsustainable soil management practices, and increase in population has exerted high pressure on the fragile soils of Ethiopia, thus a serious environmental problem that yearns for sustainable solution. Warra et al. (2015) in Kacho catchment, southeastern Ethiopia, assessed some soil quality indicators as a function of topographic aspects and changes in land cover. From the study, soil degradation index results showed that SOC content declined due to change in land cover from natural vegetation to cropland. Due to the negative impact of agricultural management practices in their study, Warra and co advocated for an integrated land resource management for restoration of the degraded land in view of sustaining agricultural growth and productivity.

In a study to evaluate the capability of dry Afromontane forest of Danaba, Oromia Regional State of Ethiopia for $\mathrm{CO}_{2}$ mitigation potential, Bazezew et al. (2015) estimated that the SOC density at $30 \mathrm{~cm}$ depth was $186.40 \mathrm{t} \mathrm{ha}^{-1}$ which is equivalent to $684.09 \mathrm{CO}_{2}$. From sustainability point of view, integration of carbon sequestration with Reduced Emission from Deforestation and Degradation (REDD+) and Clean Development Mechanism (CDM) carbon trading system of the Kyoto Protocol was advocated by the authors in order to obtain financial value of $\mathrm{CO}_{2}$ mitigation.

In a meta-analysis to review the effect of long-term land management practices on SOC in Ethiopia, Shiferaw et al. (2013) reported SOC values of 1.7, 2.6, and $2.8 \mathrm{~g} / \mathrm{kg}$ for cropland (CL), grassland (GL), and forestland (FL) respectively, with ranking order of variability as $\mathrm{FL}>\mathrm{GL}>\mathrm{CL}$. With emphasis on biomass and soils, the review reported that accelerated carbon depletion within two cropping seasons occurs on an estimated 0.2 million ha and 8 million ha for forestlands and cropping lands respectively. The use of SOC as a major indicator for showing the sustainability of long-term management practices across various landscapes was the major finding of Shiferaw and co. However, focusing mainly on studies from southern parts of Ethiopia was a major limitation of this review, thus not a clear representative of the whole country.

Significant scientific evidence abounds to justify that climate change is a rapidly growing global dilemma and Ethiopia is actually feeling the impact. Low SOC content is a major characteristic of most soils in northern Ethiopia (Girmay et al. 2008) thereby leading to structural degradation and decline in soil quality, thus the urgent need for sustainable best management practices for enhanced SCS. Soil carbon depletion across Ethiopia (mainly in the highlands) has been very severe due to high increase in population, deforestation, agricultural intensification, and high livestock pressure (Assefa et al. 2017), thus militating against sustainable agricultural productivity.

With focus on semi-arid area of northern Ethiopia at a watershed level, SOC showed a declining trend with depth within and among most land uses in both magnitude and differential concentrations as reported by Gelaw et al. (2014). Dominant soils in the study area are Arenosols, and association of Arenosols with Regosols (WRB 2006). The land uses under consideration were rainfed crop production (RF), agroforestry-based crop production (AF), open communal pasture (OP), silvopasture (SP), and irrigation-based fruit production (IR). Their study focused on $0-30 \mathrm{~cm}$ depth and showed high potential of SOC sequestration when croplands are converted to grasslands or with the systematic integration of suitable agroforestry trees in croplands. The trend of SOC stock $(0-30 \mathrm{~cm})$ were $25.8,16.1,52.6,24.4$, and $39.1 \mathrm{Mg} \mathrm{ha}^{-1}$ in $\mathrm{AF}, \mathrm{RF}, \mathrm{OP}, \mathrm{IR}$, and SP land uses, respectively. Dissimilarities in soil types and management practices across different land uses may have contributed to the variations in $\mathrm{C}$ concentrations within the watershed. Furthermore, at watershed level in a semi-arid area of northern Ethiopia, Gelaw et al. (2015a) assessed the influence of land use on SOC and total nitrogen (TN) storage and reported highest SOC concentration $\left(12.6 \mathrm{~g} \mathrm{~kg}^{-1}\right)$ in open pasture land use at $0-15 \mathrm{~cm}$ soil depth. Other land uses considered in the study includes rainfed crop production, agroforestry-based crop production, silvopasture, and irrigation-based fruit production. Their study suggested that conversion of rainfed cultivation into grass and tree-based land use systems holds huge restoration potential for sequestration of SOC.

Hailu (2010) asserted that the degraded highlands of northern Ethiopia, which are mainly Vertisols, Luvisols, and Cambisols, are at a low level of organic carbon based on Landon (1991) nutrient rating. This assertion collaborates previous submissions of Girmay et al. (2008), Assefa et al. (2017) and Berihu et al. (2017) whom reported significant loss of SOC in highlands of northern Ethiopia. Some human activities such as unsustainable agricultural practices in Ethiopia (continuous cropping without fallowing, total harvest, bush burning) have resulted in significant emission of carbon dioxide $\left(\mathrm{CO}_{2}\right)$ to the 
atmosphere thus giving rise to massive depletion of carbon stock in both soils and biomass (Shiferaw et al. 2013). According to Stockmann et al. (2013), quantifiable global warming currently being experienced is a result of the increase in atmospheric $\mathrm{CO}_{2}$-from about 280 to more than $380 \mathrm{ppm}$ over the past 250 years.

Corral-Nuñez et al. (2014) evaluated the status of soil organic matter (SOM) in croplands and exclosures (protected areas) in northern Ethiopia. The SOM was converted to SOC for ease of reporting in conformity with other reported studies. Appreciable depletion of SOC content in farmlands $(1.2 \%$ to $1.7 \%)$ with significant increase in SOC content $(1.5 \%$ to $3.2 \%$ ) was observed in exclosures following 20 -year protection and recovery period. In assessing the role of forests and soil carbon sequestration on climate change mitigation, Alemu (2014) asserted that more than $80 \%$ of the total terrestrial aboveground $\mathrm{C}$ and $70 \%$ of the total belowground SOC is sequestered by the forest ecosystems. The study emphasized the need for adequate protection of the existing remnant forests, which serves as major terrestrial carbon sink. The above scenario (protection of the forest remnants) is pivotal to restoration of $\mathrm{SOC}$ in degraded landscapes of northern Ethiopia. In investigating the SOC and N stocks of different land use systems along a climatic gradient in northwest Ethiopia, Assefa et al. (2017) reported that 60\% of the total SOC stocks were found in the topsoil (0$10 \mathrm{~cm}$ ). More so, clear vertical gradient in SOC stock were observed down the soil profile in forests, considering the following soil depths: $0-10 \mathrm{~cm}, 10-$ $20 \mathrm{~cm}, 20-30 \mathrm{~cm}$, and $30-50 \mathrm{~cm}$. With emphasis on Desa'a dry Afromontane forest in northern Ethiopia, Berihu et al. (2017) investigated the impact of changes in land use-land cover on concentrations of SOC and TN sequestration. The study revealed significant difference in SOC distribution among dense forest $(2.3 \%)$, open forest $(1.7 \%)$, open grazing land (1.6\%), and cropland (1.2\%). More so, higher SOC $\left(44.9 \mathrm{t} \mathrm{ha}^{-1}\right)$ was sequestered in the top soil (0$20 \mathrm{~cm})$ compared to the subsoil layer $(20-40 \mathrm{~cm})$. Their findings indicated that the current management practice at the Desa'a forest area is not sustainable and advocates for more sustainable practices to avoid further degradation of the remnant of the forest. They further indicated that conversion of forestland to other land use might result in huge loss of SOC and other essential soil nutrients.

In northern highlands of Ethiopia, Miheretu and Abegaz (2017) studied the apparent changes in some soil properties as an impact of different land uses and slope position. The study reported a decline in soil fertility as a result of changes in land uses from forest to grazing and cropland. Significantly $(p<$ $0.05)$ lower concentration of soil organic carbon was found in cultivated land relative to the forested land. Significant variations in SOC content and selected physico-chemical soil properties were observed as a result of differences in slope positions. Haileslassie et al. (2005) assessed the drivers of soil nutrient depletion in Ethiopia with focus on smallholders' mixed farming systems with the application of partial versus full nutrient balances. Crop production, fertilizer use, and land use histories/land management practices were the data collected courtesy of agricultural sample survey. On the other hand, soil properties, rainfall distribution, and different land use types were processed using geographic information systems (GIS). Excluding areas under permanent and vegetable crops, the soil nutrient stocks across all regions of Ethiopia were found to be decreasing. The assessment indicated that removal of residues, total harvest, and leaching losses accounted for the major causes of nutrient losses under permanent and vegetable cropping while erosion accounted for the major causes of nutrient losses in under cereals and other annuals.

Welemariam et al. (2018) assessed the impact of exclosures and soil and water conservation (SWC) practices on SOC concentration, SOC stock, and microbial biomass carbon in the highlands of northern Ethiopia. They reported that exclosures with terraces gave the highest SOC stock ( $29 \mathrm{Mg} / \mathrm{ha})$ followed by exclosures only $(24 \mathrm{Mg} / \mathrm{ha})$, terraces $(21 \mathrm{Mg} / \mathrm{ha})$, and non-conserved grazing lands $(16 \mathrm{Mg} / \mathrm{ha})$. The topsoil layer $(0-15 \mathrm{~cm})$ recorded significantly higher $(24 \mathrm{Mg}$ $\left.\mathrm{C} \mathrm{ha}^{-1}\right)$ SOC stock than the lower $(15-30 \mathrm{~cm})$ soil depth $\left(20 \mathrm{Mg} \mathrm{C}^{-1}\right.$ ). Welemariam and co advocated for the integration of SWC measures in exclosures in order to derive the synergistic benefits of the sustainable practices in view restoration of degraded lands of the region and increasing SOC stock.

In view of the foregoing and from the available works on SOC in Ethiopia, virtually all the researchers reported change in carbon pool with soil depth. Change in land uses from forest to cultivated and grazing land leads to appreciable depletion of SOC content. The topsoil was found to sequester more carbon than the subsoil across various landscapes in Ethiopia. Generally, this particular trend was observed across different agroecological zones of Ethiopia irrespective of the soil type. This assertion underscores the importance of adopting sustainable management practices to reduce accelerated release of $\mathrm{C}$ from the fragile topsoil. Conversion of 
grasslands and croplands to forest and exclosures has been found to significantly increase SOC content. However, there are continued threats to the remaining primary forests in Ethiopia, which serves as a major sink for aboveground and belowground $\mathrm{C}$ alike (Berihu et al. 2017). Removal of $\mathrm{CO}_{2}$ from the atmosphere by plants has been recognized by the Climate Change Treaty (Kyoto Protocol) as a very effective approach for climate change mitigation while long-term studies on $\mathrm{C}$ stocks to monitor the dynamics and distribution under various land uses has been advocated for (Marland et al. 2007). Potential adverse impacts of global warming in Ethiopian context include increased incidences of floods, tropical storms, and recurring droughts; runoff; changes in the pattern and amount of rainfall distribution; and fluctuations in the amount and intensity of sunshine and coastal marine disruption. Thoughtful mitigation measures will be an ideal approach for controlling atmospheric $\mathrm{CO}_{2}$ with the adoption of strategies that promotes increasing $\mathrm{C}$ storage and reducing $\mathrm{CO}_{2}$ emissions (USGS 2008). Land degradation and climate change are the two major drivers of exacerbated environmental problems in Ethiopia (NMSA 2001; Niles et al. 2010).

Our review indicated that $33.3 \%$ of the studies reported SOC concentration, $13.9 \%$ reported only SOC stock while $52.8 \%$ reported both SOC concentration and stock (Table 2). However, studies focusing on 0 $30 \mathrm{~cm}$ only were $44 \%$, other studies extending up to 40 to $100 \mathrm{~cm}$ were $50 \%$, and studies extending more than $100 \mathrm{~cm}$ accounted for $2.8 \%$ while studies without any depth specification accounted for $2.8 \%$ (Table 3).

It should also be noted that owing to the heterogeneity of Ethiopian soils, coupled with the different climatic settings and varying soil properties, current scientific knowledge and available data on soil carbon stock remains insufficient and also distorted. Absence of long-term field trials/experiments on SOC in Ethiopia is another research gap identified in this review which yearns to be addressed, and if

Table 3 Various depths reported in referred articles

\begin{tabular}{lll}
\hline Depth* & $\begin{array}{l}\text { Number of } \\
\text { observations }\end{array}$ & $\begin{array}{l}\text { Percentage } \\
\text { proportion (\%) }\end{array}$ \\
\hline $0-30 \mathrm{~cm}$ only & 16 & $44 \%$ \\
40 up to $100 \mathrm{~cm}$ & 18 & $50 \%$ \\
$>100 \mathrm{~cm}$ & 1 & $2.8 \%$ \\
No depth specification & 1 & $2.8 \%$ \\
Total & 36 & 100
\end{tabular}

*See Appendix 1 for details implemented will form a vital input for modeling SOC changes over time.

For more precision and accuracy in SOC studies, incorporation of GIS and remote sending (RS) approach in SOC studies has received considerable global attention but is rather proceeding slowly in Ethiopia. Few studies in Ethiopia focused mainly on SOC distribution using GIS and RS (Vågen et al. 2012, 2013). However, majority of the studies involving RS and GIS focused basically on land use cover/ change (Asmamaw et al. 2011; Kindu et al. 2013; Hailemariam et al. 2016; Demissie et al. 2017; Birhane et al. 2019), land suitability/capability for crop production (Kahsay et al. 2018; Yohannes and Soromessa 2019), and erosion or soil loss modeling (Mellerowicz et al. 1994; Israel 2011; Gebreyesus et al. 2014; Woldemariam et al. 2018). Integration of GIS and RS in SOC studies can increase our power of precise prediction in terms of SOC storage and dynamics under different land use types in modulable scenarios of changing climate. With focus on Ethiopian soils, Vågen et al. 2013 reported that predictions based on Landsat reflectance were quite robust (SOC $R^{2}=0.79$ ), thus a reliable basis of creating predicted surface maps for SOC and related soil properties. Therefore, the implication of this result is that incorporating GIS and RS in SOC studies will increase our level of precision in predicting SOC storage and changes over time.

In view of increased land use intensification due to the increasing food, energy, and water demand for the teeming world population Foresight (2011), proper soil management practices (details discussed in the section below) for enhanced carbon storage is very pertinent to conserve this valuable natural resource for future generations, especially in Ethiopia where land degradation is on the increase.

\section{Options for increasing soil organic carbon stock in Ethiopia and in the tropics}

It is very imperative to identify and select wide range of feasible approaches that are environmentally friendly and which aim to reduce $\mathrm{CO}_{2}$ emissions and promote $C$ sequestration. Robert (2006) asserted that effective soil $\mathrm{C}$ sequestration can be achieved through the following means: (i) conversion of cropland to forest or pasture/paddock-accounting for $0.5 \mathrm{t} \mathrm{C} / \mathrm{ha} /$ year average increase; (b) adoption of conservation agriculture and change in agricultural management practices that deplete soil $\mathrm{C}$ and overall soil qualitye.g., raised-bed cultivation in arid region, no-tillage, avoiding total harvest by leaving 30\% residue or cover crops on the surface of the soil. This assertion is in line with similar studies across different regions of 
Ethiopia where improvement in $\mathrm{C}$ stock has been recorded with conversion of arable and grazing land to forest and/or exclosure (Mekuria 2013; Mekuria and Yami 2013; Assefa et al. 2017). Revegetation and afforestation has been recommended as effective approaches for atmospheric $\mathrm{CO}_{2}$ reduction to ensure $\mathrm{C}$ sequestration in both soils and vegetation (IPCC 2012). The conversion of native forests to plantations, croplands, and other unsustainable land uses negatively influenced the SOC pool in soils across Ethiopia (Demessie et al. 2015; Berihu et al. 2017).

In Ethiopia, significant increase in SOC and improvement of ecosystem services has been achieved through the conversion of open grazing lands to exclosures (protected areas with zero grazing and prohibition of human activities) across different agro-ecological zones (Descheemaeker et al. 2006a, 2006b; Corral-Nuñez et al. 2014; Assefa et al. 2017; Welemariam et al. 2018). For example, Corral-Nuñez et al. 2014 studied the current and predicted SOM in northern Ethiopia and reported significant recovery of SOM ranging from 2.6 to $5.6 \%$ in exclosure after 20 years compared to $2.1 \%$ to $2.9 \%$ in cropland. They opined that the low SOM content in croplands was due to mono-cropping, planting on steep slopes, non-retention of residues, and use of residue and animal manure as energy source for cooking. More so, Assefa et al. 2017 reported that the conversion of a degraded open grazing land to exclosure significantly increased SOC stock in the topsoil layer $(0-10 \mathrm{~cm})$ by 42\%. Similarly, Welemariam et al. 2018 studied the impact of different land use and management practices on SOC and reported that exclosures backed up with community-based soil and water conservation practices increased SOC stock. Their result indicated that exclosure with terraces, exclosures alone, terraces, and non-conserved open grazing lands gave 29, 24, 21, and $16 \mathrm{Mg} \mathrm{C} /$ ha respectively. Welemariam and co therefore advocated for the establishment of exclosures and construction of terraces in open grazing lands as possible ways of increasing SOC stock and restoration of degraded lands.

Apart from being protected from grazing and any form of human activity, these exclosures are home to so many soil and water conservation (SWC) practices and technologies which are very instrumental in the land restoration and regeneration processes. For example, rural communities in Ethiopia has made concerted efforts over the past few decades in erecting stone terraces, soil bunds and other physical barriers on the farmland, establishment of exclosures, and taking active part in voluntary tree planting projects through coordinated free-labor (Mitiku and Kindeya 1998; Fitsum et al. 1999; Reda 2015). Currently, over
$75 \%$ of the smallholder farmers in Ethiopia practices terrace construction on their farmlands (Nyssen et al. 2007). These restoration approaches by the local communities have been instrumental in restoration of the degraded lands of Ethiopia especially in the northern semi-arid area while improving the native SOC content for sustainable agricultural productivity. Afforestation of degraded croplands and grazing lands with eucalyptus increased SOC stock to nearly $70 \%$ of the natural forest levels within 30 years in northwest Ethiopia (Assefa et al. 2017). In most regions of Ethiopia, establishment of exclosures has successfully removed grazing pressure, thus allowing gradual regeneration of native vegetation, with significant increase in SOC especially within the top soil layer. Significant improvements with the establishment of exclosures on open grazing lands in rural communities of Ethiopia especially relating to increasing SOC and regulating ecosystem services is well documented (Wolde and Veldkamp 2005; Yayneshet et al. 2009; Mekuria 2010, 2013; Mekuria and Yami 2013; Ubuy et al. 2014; Assefa et al. 2017).

It is worthy of mention that land degradation is synonymous to loss of soil nutrient and depletion of SOC, thus any concerted effort to restore the degraded lands through appropriate soil management practices will eventually lead to increased SOC status and decrease in $\mathrm{CO}_{2}$ emission. Organic amendments (for example animal manure, crop residue, vermicompost, and green manure), if incorporated into the soil, has the capacity of maintaining and enhancing soil quality, in addition to improving the native nutrient pool (Agegnehu and Amede 2017). Organic amendments in addition to acting as precursors to soil organic matter (Agegnehu et al. 2012) also acts as a major factor in enhancing availability of nutrient, improving soil water content and recycling of nutrient in the ecosystem, as well as addition of nutrients to the stock (Amede et al. 2003), thus a good soil conditioner for sustainable agriculture.

Thus, approaches that enhance SOC increment in agricultural ecosystems systematically improve atmospheric $\mathrm{CO}_{2}$ sequestration as well as organic-matter pools restoration, which is very critical to soil quality and health (Hooker et al. 2005). Nevertheless, important drivers for effective sequestration of SOC includes increased plant growth and productivity, increased net primary production, reduced rate of decomposition (Tieszen 2000), stabilization of carbon in the subsoil, organic amendment application to the soil (Powlson et al. 2011), and biochar application (Sohi et al. 2010; Verheijen et al. 2009). Substantial increase in the total soil $\mathrm{C}$ pool with the application of biochar from various sources is well documented (Steiner 2010; Matovic 
2011; Mekuria and Noble 2013; Jiang et al. 2013; Woo 2013; Mbah et al. 2017). For instance, Nigussie et al. (2012) reported $0.71 \%$ C increment on a Nitosol in southeastern Ethiopia following the incorporation of maize stalk biochar ( $5 \mathrm{t} \mathrm{ha}^{-1}$ ) compared to a control (unamended plot). However, Lal (2016) submitted that biochar impact on soil $\mathrm{C}$ dynamics is dependent on biochars' properties in relation to the feedstock, pyrolysis, antecedent soil characteristics, and management systems. More so, Sohi et al. (2009) as reported in Mekuria and Noble (2013) argued that the extent of the impact of biochar application on soil carbon sequestration (SCS) and agricultural production remains variable and not fully understood mainly due to the different soil processes (chemical, physical, and biological) and biophysical interactions occurring due to biochar application, which yearns for more critical study for clear understanding. Conservation tillage, cover crops, integrated soil fertility management (ISFM), irrigation, restoration of degraded soils, management of pasture lands, forest soils, stabilization of carbon in subsoil, and afforestation (see Lal 1998; Lal 2008b; Lal et al. 2012) are among the recommended soil and crop management practices acting individually and collectively to improve the SOC pool in the terrestrial ecosystem.

Jobbagy and Jackson (2000) argued that crop production in addition to various forms of biomass distribution strongly affect $\mathrm{C}$ distribution within the soil profile, thus SOC will probably be stored longer with long residence time in deeper soil profiles (Stockmann et al. 2013). With the implementation of recommended management practices (RMPs) and best management practices: conservation tillage, mulch farming, compost, elimination of bare fallow, integrated nutrient management, reclamation of eroded soils, restoration of salt affected soils, water conservation and management, afforestation, grassland and pastures, conservation tillage, use of cover crops, integrated soil fertility management, and improved grazing (Lal 1998; Lal 2008b), SOC can accumulate in soils owing to minimized/reduced erosion losses and attendant increase in the quantity and quality of biomass being returned to the soil. Increased soil water conservation, improved soil health and overall soil quality, and SOC pool enhancement are among the benefits of adopting these practices (Lal 2004). According to Lal (2004a, 2004b), common RMPs in line with the principles of keys to successful SCS include (i) conservation-effective measures that minimizes attendant risks of runoff and soil loss (erosion) for example, conservation agriculture (CA) comprising no-till (NT) farming, mulching, cover cropping, green manuring, and integrated nutrient management (INM) that provide adequate amount of plant nutrients for improved crop productivity that enhance biocomplexity and provide a continuous ground cover such as cover cropping and integration of crops with livestock (Lal 2015a, 2015b); (ii) growing deep-rooted plants to transfer $\mathrm{C}$ into the subsoil such as agroforestry; and (iii) adding recalcitrant material into the soil that is quite resistant to decomposition by microorganisms and has long mean residence time (MRT) (e.g., use of biochar).

In the face of intense land degradation in Ethiopia, adopting the integrated nutrient management (INM) or ISFM strategy together with RMPs is very important for effective SOC sequestration. For example, with the application of manure and other organic amendments, Corral-Nuñez et al. (2014) reported that the amount of SOM increased from 2.1 to $2.9 \%$ in cultivated soils of semi-arid area of northern Ethiopia. Mekonnen (2006) stated that the incorporation of organic manure together with mineral fertilizer in a Nitosol in Southern Ethiopia increased organic carbon by $8.68 \%$ over the initial status. A 2-year field experiment conducted on a strongly acid clay loam (Haplic Alisols) soils in southern Ethiopia using farmyard manure (FYM) and mineral fertilizer (NPK) recorded significant increase in total organic carbon in amended plots over unamended control plots (Boke 2014).

Lal (2004b) posited that the implementation of a land use restoration approach and RMPs on cultivated soils can lead to decrease in atmospheric $\mathrm{CO}_{2}$ emission thus leading to improved food security, enhanced water quality, and environmental sustainability. Restoration of significant portion of the depleted SOC pool is achievable with the implementation of restoration of degraded lands, adoption of ISFM, conservation agriculture, in addition to other sustainable management practices that improve SOC in the ecosystem (Lal 2004a, 2004b; Powlson et al. 2011). With the adoption of RMPs, Lal (2004a) submitted that SOC rates of 50 to $1000 \mathrm{~kg} / \mathrm{ha} /$ year and $0.9 \pm 0.3 \mathrm{Pg} \mathrm{C} /$ year for measurable rates and global potential rates of $\mathrm{SOC}$ sequestration, respectively, can be achieved.

Powlson et al. (2011) posited that the following examples of land management practices increase SOC: conversion of cultivated land to forest or grassland, restoration of degraded lands with the introduction of resilient trees/shrubs, use of organic amendments, adoption of reduced-tillage in cropping systems, stabilization of carbon in subsoil, and biochar application.

Maximizing the quantity of SOC that might be stored in landscapes at regional and global level can be a veritable tool for climate change mitigation and 
improving soil quality (Stockmann et al. 2013). Loveland and Webb (2003) proposed a critical value of $2 \%$ SOC with a resultant significant depletion in soil quality below the critical value in cultivated soils of temperate regions. However, the critical value of $2 \%$ SOC content advocated in temperate regions is yet to be verified for tropical soils (Patrick et al. 2013) where soil degradation and decrease in soil fertility has continued unabated and currently at its peak. In a review of data from dryland sites, Janzen et al. (1998), as reported in Krull et al. (2003), showed that dry matter yields decrease after soil organic matter levels fall below 2\%. Hassink (1997) as reported by Stockmann et al. (2013) posited that critical concentration of SOC $(\sim 1.5 \%$ and $\sim 0.8 \%$ for sandy and clay soils respectively) may be recommended as guide for farmers. Recarbonization of biosphere $C$ as opined by Lal et al. (2012) is another viable option and sustainable approach for $\mathrm{C}$ sequestration and special emphasis should be on restoration of soil C pools, which comprises the soil inorganic carbon (SIC) and SOC pools. In addition to ensuring mitigation and adaptation to climate change, the recarbonized soils further ensures significant restoration of SOC pool which improves soil quality, ecosystems services, sustainable agricultural productivity, and food security (Lal 1998; Lal 2008b).

The objective of these land management practices and best management practices as outlined by Lal $2008 \mathrm{c}$ is to ensure a positive $C$ budget with improved quality and efficient natural ecosystem. Wide range of degraded soils abounds with SOC pool highly depleted particularly in the tropics. Degradation by erosion and depletion of essential nutrients are quite significant among degraded soils (Girmay et al. 2008). Numerous benefits exist due to restoration of degraded soils, which includes improved water quality and reduction in $\mathrm{CO}_{2}$ emissions as a result of increased biomass production (Stockman et al. 2013). Close to 750 million ha of degraded land has been estimated by Grainger (1995) to exist in the tropics with prospects of soil quality improvement and, reclamation and afforestation. The SOC sequestration capability is close to 0.5 Megagram $(\mathrm{Mg}) \mathrm{ha}^{-1}$ year $^{-1}$ while 1.1 Pg C year ${ }^{-1}$ is estimated to be the SOC sequestration of 750 million ha. In soils of arid and semi-arid areas, Lal (2001) estimated 0.4-0.7 Pg C year ${ }^{-1}$ SOC sequestration potential with the adoption of desertification control strategies. Elsewhere, Squire et al. (1995) has reported comparable estimates.

In addition to the management practices aforementioned, there are well formulated national polices (for instance, conservation and ecosystem strategies, environmental protection policy, and Ethiopian government policy on fertilizer), ratified governmental laws and proclamations, action plan, and strategic work plans geared toward enhanced SCS in Ethiopia (Shiferaw et al. 2013) but requires proper monitoring and evaluation to achieve the desired goals. According to the report of BoPED (1995), the National Forests Priority Areas (NFPAs) in Ethiopia that are 59 in number is an offshoot of the national policies coupled with the exclosures being established by local communities in addition to church forests being established by the Ethiopian Orthodox churches. Establishment of exclosures and church forests is seen as a sustainable approach to restoration of degraded lands across Ethiopia following intense exploitation of the NFPA's. It is noteworthy that these exclosures were established on areas formerly used as community open grazing lands (Aerts et al. 2009; Mekuria and Aynekulu 2013) with the main purpose of revegetation, restoration of forest lands, conservation of marginal lands, and restoration of degraded lands (Nyssen et al. 2015). This approach helps to maintain biodiversity in the drylands by protecting the degraded lands from the intrusion of humans or livestock (Mekuria and Aynekulu 2013). However, protection of the forest remnants is very important to avoid continuous deforestation and further land use conversion (as is the case in most parts of Ethiopia) in order to ensure huge improvement of SOC stocks and strong ecosystem services and functions (Demessie et al. 2015). Restoration of degraded Ethiopian landscapes with the establishment of exclosures and protection of the forest areas for enhanced carbon sequestration potential of soils would enable Ethiopia to partake in the Clean Development Mechanism (CDM). If adopted, this will ensure improvement of the livelihood of the poor smallholder farmers in addition to accruing economic benefits arising from payments for $\mathrm{C}$ credits (carbon emission reduction [CER] credits) in conjunction with developed countries.

Furthermore, documented evidences exist regarding the role of Ethiopian Church forests in restoration of degraded lands, atmospheric $\mathrm{CO}_{2}$ reduction, and ecosystem service regulation (Wassie and Teketay 2006; Eshete 2007; Tura and Eshetu 2013; Cardelús et al. 2013a, 2013b; Abiyu et al. 2018). Widely adored and revered because of its religious and sanctifying status under the protection of the Ethiopian Orthodox Tewahido Church [EOTC] (Wassie 2002), the Ethiopian Church forests serves as sanctuary and sacred abode to diverse species of flora and fauna. It also plays a huge significant role in conservation of biodiversity (Bongers et al. 2006; Wassie and Teketay 2006; Cardelús et al. 2013a). Population pressure coupled with recurrent extreme weather conditions (drought, flooding, etc.) has over time been posing a great threat to the remnants of the church forests. 
Abiyu et al. (2018) however submitted that approximately $35 \%$ of church forest disturbances in Ethiopia are attributed to climate extreme events, which is a strong indication that the disturbance is anthropogenically and climatically induced.

With more concerted efforts toward effective safeguarding approaches, church forests, in addition to being more protected than other forests (Tura and Eshetu 2013), also sequesters more $C$ both above and belowground (Descheemaeker et al. 2006a, 2006b; Cardelús et al. 2013b; Aerts et al. 2016). Tura and Eshetu (2013) reported that the average trend in $\mathrm{C}$ storage in church forests is $0.6+0.69 t, 0.6+0.69 t, 17.83+19.13$, and $135.94+21.25 \mathrm{t} \mathrm{ha}^{-1}$ for aboveground (AG) biomass carbon per tree, mean above ground biomass carbon per tree, dead litter, and soil $\mathrm{C}$ respectively. Comparing young exclosures, middle-aged exclosures, old exclosures, grazing lands, and church forests, Descheemaeker et al. (2006b) reported that church forest sequestered more SOC compared to other agroecosystems. More so, Mekuria et al. (2009) reported that the average SOC at the topsoil layer and AG carbon stock of church forest were $52.7 \mathrm{MgC} \mathrm{ha}{ }^{-1}$ and $21.3 \mathrm{MgC} \mathrm{ha}{ }^{-1}$ respectively. This implies $36-50 \%$ and $39-68 \%$ increment in soil and aboveground carbon stocks due to conversion of degraded grazing lands to exclosures. Recently, Gebremedhin et al. (2017) investigated the impact of converting grazing land into cultivated lands in northern Ethiopia and reported significant loss of SOC and other studied fertility indices. Distribution of SOC in the study was $11.5,5.3,6.9,4.7,4.8$, and $4.6 \%$ for Church forest, seasonal grazing land, open grazing land, 6-year exclosure, 16-year exclosure, and 20-year exclosure respectively. Thus in view of the foregoing, it can be clearly observed that $\mathrm{C}$ storage in church forest is relatively higher compared to exclosures and other land uses. Detailed study by Wassie and Teketay (2006) with emphasis on soil seed banks in church forests of northern Ethiopia indicated that huge amount of persistent seeds of herbaceous species accumulates in church forest soils in great magnitude thus leading to increased soil $\mathrm{C}$ storage and stabilization.

However, with persistent encroachment on the existing and remnants of church forests, it has been proposed that erection of fences, controlling grazing pressure, and promotion of planting seedlings will go a long way in maintaining and restoring of church forests in the rugged landscape of northern Ethiopia (Wassie et al. 2009; Aerts et al. 2016).

\section{Evidence of payments for carbon credits in Ethiopia}

As the second largest country in Africa after Nigeria (Worldometers 2018), Ethiopia is targeting significant economic transition toward attaining middle-income status in addition to achieving its net carbon neutral goal by the year 2025 . However, with over $85 \%$ of its population dependent on agriculture, natural disasters such as droughts and floods exerts tremendous social and economic impact. According to Arens and Burian (2012), only Ethiopia among the least developed countries (LDCs) to develop CDM projects has the highest technical potential, projected at about 32 million certified emission reductions (CERs) annually.

The Oromia Forested Landscape Program (OFLP) in the southern part of Ethiopia harbors Ethiopia's largest concentration of biodiversity. Domiciled in Ethiopia's massive Oromia region, which constitutes $34.3 \%$ of the country's landmass, OFLP appears to be the country's most prominent program to mobilize resources toward its net carbon neutral by 2025 goal. Established with two World Bank funds, the $\$ 68$ million OFLP project, aims at the restoration of forests on degraded lands ( $\$ 18$ million) and for programs targeting carbon sequestration assessment and performance enhancement (\$50 million) respectively (CDM Overview). The OFLP will receive payments of up to $\$ 50$ million for verified carbon credits against an agreed forest reference emission level from the World Bank for a decade. The forest reference emission level is part of a critical policy framework that gives countries a point to measure the results they have gained from REDD+ (reducing emissions from deforestation and forest degradation in developing countries) implementation.

At the continental level, the Humbo natural regeneration (reforestation) project managed by World Vision and registered under the CDM in December 2006 with a 30-year lifespan is the only significant carbon finance project currently active in Ethiopia (Mulugetta 2011). Established on 2728 ha of land, the project has won global recognition as Africa's first carbon credits for reforestation. Reported evidence by the Federal Democratic Republic of Ethiopia (2015) indicates that the area has $880,000 \mathrm{t}$ of carbon dioxide stock which is equivalent to USD 13.2 million over 30 years. In general, with more than 18 million ha of forests covering about $16 \%$ of its land area, Ethiopia has a vast potential and is among the countries partnered with Forest Carbon Partnership Facility (FCPF) to implement REDD+ (Gonzalo et al. 2017). The total forest carbon stock is estimated at 2.7 billion according to the Federal Democratic Republic of Ethiopia (2015) report. Currently, the country has more than 13 protected areas for biodiversity and wildlife conservation covering a total land area of 3.7 million ha of land. Out of the total, six preserved areas with a combined total of 1.2 million ha of land have a forest carbon approximately 60 million metric tonnes. More so, various afforestation and 
reforestation programs are still ongoing nationwide and at different levels of development and transition.

In view of the foregoing, the recent United Nations Gold Future Policy Award 2017 won by Ethiopia, beating 26 other nominated policies to the prize through the sustainable practices of Tigray region on land restoration portend "potentially marketable" areas for carbon trading in Ethiopia. It is worthy to mention that the recent United Nations Gold Future Policy Award 2017 won by Ethiopia actually represents unique collective, well-coordinated action, voluntary labor and the involvement of youths in Tigray region of northern Ethiopia in massive land restoration on a very significant large scale. Major decrease in erosion incidences, recharging of the ground water, and the adoption of sustainable agricultural practices growth were made possible as a result of the massive land restoration of the dry lands of $\mathrm{Ti}$ gray region leading to significant food self-sufficiency and economic growth. Many area exclosures established on the reclaimed degraded lands across the landscapes of northern Ethiopia poses a potential source of carbon trading (Kassahun et al. 2009) if they remain undisturbed over a long period of time with verifiable amount of carbon stock. Nevertheless, the carbon stock potential of area exclosures may not compare to that of church forests considering age of establishment and diversity in tree species and biodiversity. However, detailed studies and investigations are still required in this regard for more experimental verifiable conclusion. However, for effective participation in the global carbon trading, technical training on methods and assessment approaches for both intervention specific and economy-wide emissions accounting remains apparent and very important. At the moment, technical knowhow is limited and spread among very few professionals and non-state experts, which still remain a major setback in the Ethiopian carbon trading program.

\section{Conclusion and recommendations}

Unsustainable land management practices (deforestation, total/extractive harvesting, uncontrolled grazing, continuous cultivation without fallowing, and bush burning) being practiced in many locations in Ethiopia have been found to be a key factor in the increased $\mathrm{CO}_{2}$ emissions in the country. Our findings highlighted massive losses in soil carbon due to forest conversion to other land uses and severe $\mathrm{C}$ losses due to agricultural intensification in degraded lands. Huge differences exist in the amount of soil carbon stored within and among soil types, in relation to vegetative cover, climate, landscape configuration, and textural classes of soil across different landscapes of Ethiopia. These observed differences in the amount of stored SOC may be due to the nature of soils, type of analytical tools, and apparatus used for the respective studies. However, the topsoil layers across different landscapes in Ethiopia recorded higher SOC pool than subsoil, thus underscoring the importance of sustainable land management practices to reduce $\mathrm{CO}_{2}$ emission from the fragile topsoil layers. The establishment of exclosures by local communities in Ethiopia and continued protection of church forests proves to be a sustainable way of revegetation and land restoration in line with the United Nations Sustainable Development Goals. Thus, the introduction of carbon payments will stimulate concerted efforts among the local farmers and community dwellers to sustain the conservation of exclosures as a profit-orienting project. However, there is a need for further studies to address both biophysical and socioeconomic issues of carbon sequestration in the tropics. There should be more emphasis on the areas of future research, especially use of climate scenarios to simulate the nature and distribution of SOC over time especially below the subsoil, carbon dating, and assessment by various proxies of microbial activities to study SOC dynamics with regards to land use changes. More so, further studies should focus on subsoil carbon dynamics across different agroecological zones, which are currently less reported in Ethiopia. Soil carbon modeling has received very little attention in Ethiopia. Thus, modeling changes in SOC across the soil profile will increase our prediction of $\mathrm{C}$ dynamics. In addition to establishing SOC long-term field trials which is currently lacking in Ethiopia, current research interest should seek to focus more on the quality rather than only the quantity of SOC stored in different landscapes which is very essential to our holistic understanding of the status, composition, and behavioral dynamics of SOC in the face of changing climate. This will provide systematic understanding of SOC dynamics under heterogeneous landscape such as Ethiopia, thus highlighting the need for further studies on impact of management practices on distribution of SOC across depths. In addition to boosting agricultural productivity and ensuring sustainable agricultural development, this will equally go a very long way in stimulating the best management practices for SOC stock among the inhabitants of the region. Furthermore, it would also ensure active participation of the zone (Ethiopia) in the Clean Development Mechanism (CDM), suggested in the United Nations Framework Convention on Climate Change (UNFCCC 2002) Article 12 of the Kyoto Protocols. 


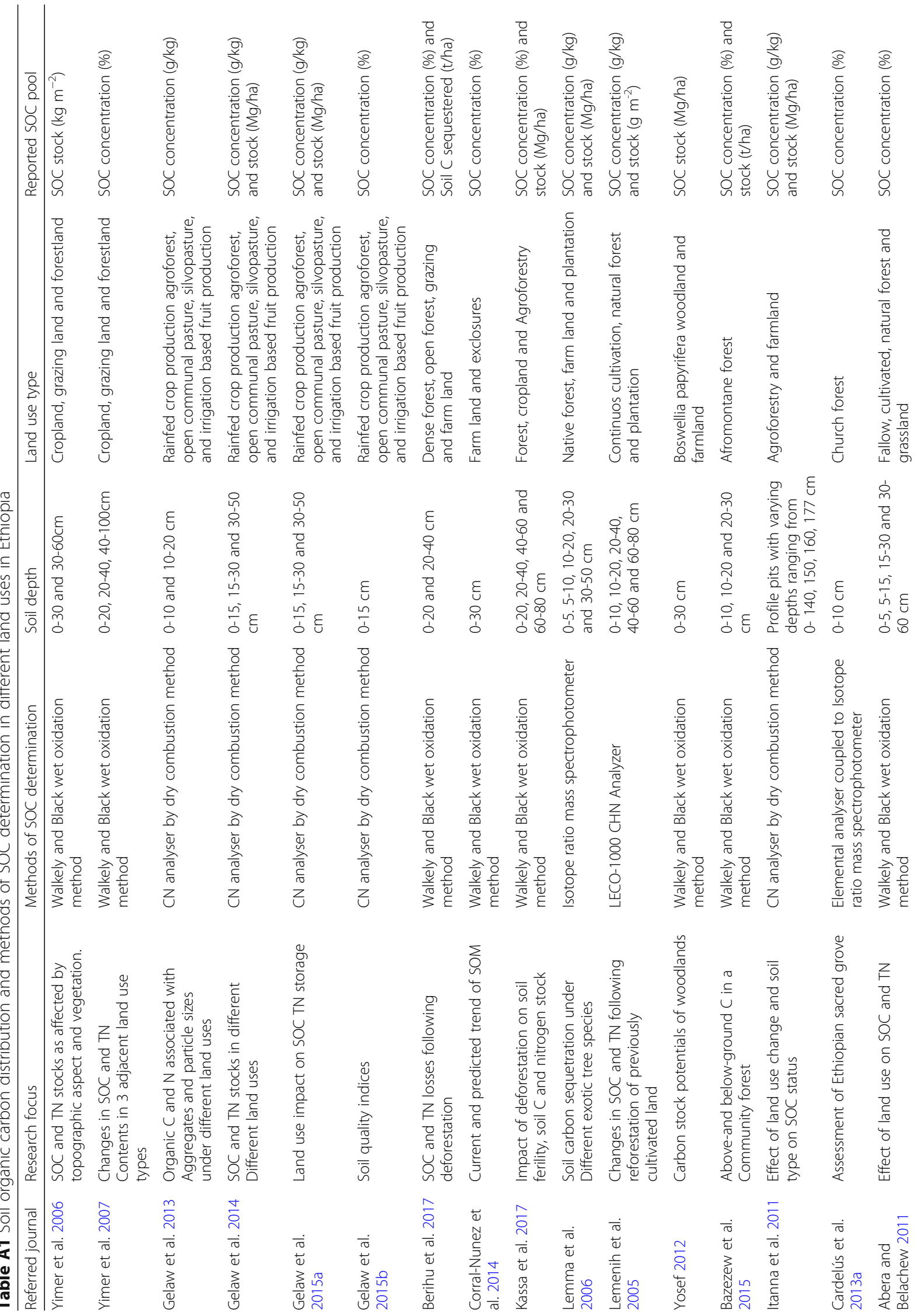




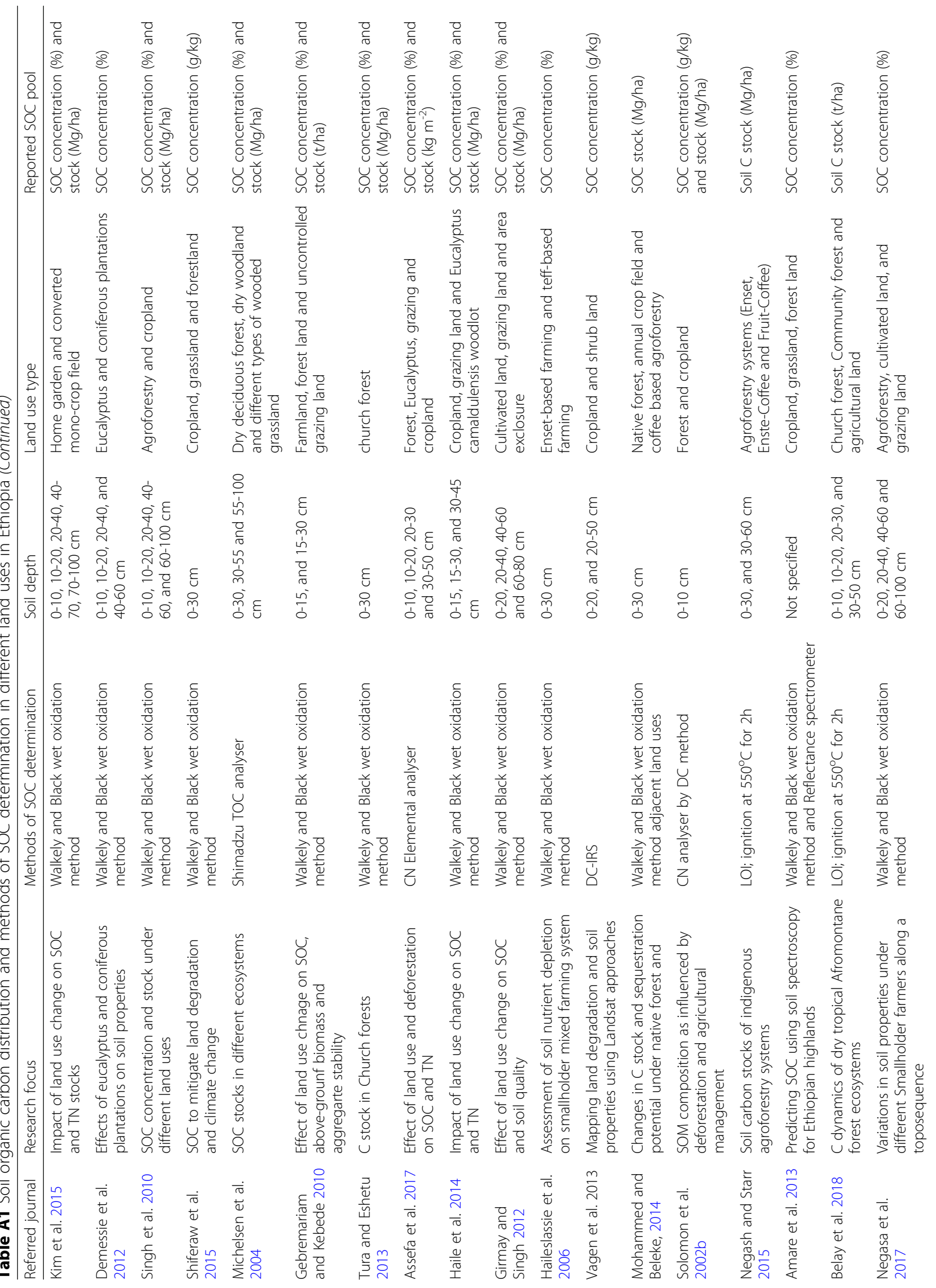




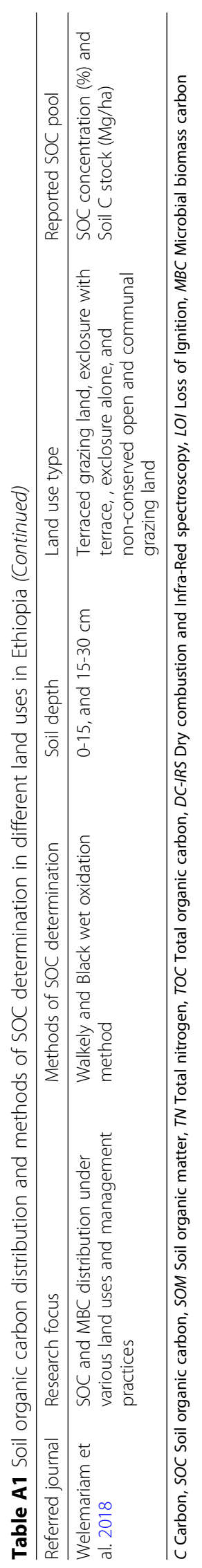




\begin{abstract}
Abbreviations
AF: Agroforestry-based crop production; AG: Aboveground; AR4: Fourth Assessment Report; BoPED: Bureau of Planning and Economic Development; C: Carbon; CA: Conservation agriculture; CDM: Clean Development Mechanism; CERs: Certified emission reductions; $\mathrm{CL}$ : Cropland; $\mathrm{CO}_{2}$ : Carbon (IV) oxide; EOTC: Ethiopian Orthodox Tewahido Church; FAO: Food and Agriculture Organization; FL: Forest land; FYM: Farmyard manure; GIS: Geographical information system; GL: Grass land; Gt: Gigatone; INM: Integrated nutrient management; IPCC: Intergovernmental Panel on Climate Change; IR: Irrigation-based fruit production; ISFM: Integrated soil fertility management; LDCs: Least developed countries; MRT: Mean residence time; $\mathrm{N}_{2} \mathrm{O}$ : Nitrous oxide; NFPAs: National Forests Priority Areas; NGOs: Nongovernmental organizations; NPK: Nitrogen-phosphorus-potassium; NT: Notill; OFLP: Oromia Forested Landscape Program; OP: Open communal pasture; Pg: Petagram; REDD+: Reduced Emission from Deforestation and Degradation; RF: Rainfed crop production; RMPs: Recommended management practices; RS: Remote sensing; SCS: Soil carbon sequestration; SIC: Soil inorganic carbon; SOC: Soil organic carbon; SOM: Soil organic matter; SP: Silvopasture; SWC: Soil and water conservation; Tg: Teragram; TN: Total nitrogen; UNFCCC: United Nations Framework Convention on Climate Change; USD: US Dollar; WB: Walkley and Black; WRB: World Reference Base for soil resources
\end{abstract}

\section{Acknowledgements}

The PhD scholarship support of Transdisciplinary Training for Resource Efficiency and Climate Change Adaptation in Africa (TRECC Africa II) to Chukwuebuka Christopher Okolo (CCO) is highly appreciated. The contribution of German Federal Ministry of Education and Research (BMBF) "Green Talents" research support to CCO is greatly appreciated. The final draft of this review was completed when CCO was at Georg-August University Goettingen as a guest researcher. The authors sincerely appreciate and thank Damasco Rubangakene for producing the map in Fig. 1. We so much appreciate the anonymous reviewers for their constructive insights in improving the quality of this work.

\section{Funding}

This study was funded by the Transdisciplinary Training for Resource Efficiency and Climate Change Adaptation in Africa (TRECC Africa II) project.

\section{Availability of data and materials}

The authors declare that the review work data and material are available. In addition, all data generated or analyzed during this study are included in this manuscript.

\section{Authors' contributions}

All authors contributed equally in all article steps. All authors read and approved the final manuscript, after editing and formatting by CCO and ANR.

\section{Ethics approval and consent to participate}

The authors declare that the work is ethically approved and consent to participate.

\section{Consent for publication}

The authors declare that the work has a consent for publication.

\section{Competing interests}

The authors declare that they have no competing interests.

\section{Publisher's Note}

Springer Nature remains neutral with regard to jurisdictional claims in published maps and institutional affiliations.

Received: 14 February 2019 Accepted: 17 April 2019

Published online: 20 June 2019

\section{References}

Abera Y, Belachew T (2011) Effects of landuse on soil organic carbon and nitrogen in soils of Bale, southeastern Ethiopia. Trop Subtrop Agroecosyst 14:229-235

Abiyu A, Mokria M, Gebrekirstos A, Bräuning A (2018) Tree-ring record in Ethiopian church forests reveals successive generation differences in growth rates and disturbance events. For Ecol Manag 409:835-844
Aerts R, Nyssen J, Haile M (2009) On the difference between "exclosures" and "enclosures" in ecology and the environment. J Arid Environ 73:762-763

Aerts R, Overtveld KV, November E, Wassie A, Abiyu A, Demissew S, Daye DD, Giday K, Haile M, Berhan ST, Teketay D, Teklehaimanot Z, Binggeli P, Deckers J, Friis I, Gratzer G, Hermy M, Heyn M, Honnay O, Paris M, Sterck FJ, Muys B, Bongers F, Healey JR (2016) Conservation of the Ethiopian church forests: threats, opportunities and implications for their management. Sci Total Environ 551-552:404-414

Agegnehu G, Amede T (2017) Integrated soil fertility and plant nutrient management in tropical agro-ecosystems: a review. Pedosphere 27(4):662-680

Agegnehu G, Tsigie G, Tesfaye A. 2012. Evaluation of crop residue retention, compost and inorganic fertilizer application on barley productivity and soil chemical properties in the central Ethiopian highlands. Ethiop J Agric Res. 22: 45-61.

Alemu B (2014) The role of forest and soil carbon sequestrations on climate change mitigation. Res J Agr Environ Manage 3(10):492-505

Amare T, Hergarten C, Hurni H, Wolfgramm B, Yitaferu B, Gebere Selassie Y (2013) Prediction of soil organic carbon for Ethiopian highlands using soil spectroscopy. ISRN Soil Article ID 720589. https://doi.org/10.1155/2013/720589

Amede T, Am'ezquita CE, Ashby JA, Ayarza MA, Barrios E, Bationo A, Beebe SE, Bellotti AC, Blair MW, Delve RJ, Fujisaka S, Howeler RH, Johnson NL, Kaaria SK, Kelemu S, Kerridge PC, Kirkby RA, Lascano CE, Lefroy R, Mahuku GS, Murwira HK, Oberth"ur T, Pachico DH, Peters M, Ramisch JJ, Rao IM, Rond'on MA, Sanginga PC, Swift M, Vanlauwe B (2003). Biological nitrogen fixation: A key input to integrated soil fertility management in the tropics. In Institut National de Recherche Agronomique (INRA) and International Crops Research Institute for the Semi-Arid Tropics (ICRISAT) (ed.) Proceedings of Workshop on Biological Nitrogen Fixation for Increased Crop Productivity, Enhanced Human Health and Sustained Soil Fertility (2002, Montpellier, France). INRA, Patancheru; ICRISAT, Montpellier. pp. 113-143.

Anikwe MAN (2010) Carbon storage in soils of southeastern Nigeria under different management practices. Carbon balance and management 5. Art No. 5. https://doi.org/10.1186/1750-0680-5-5

Arens C, Burian M (2012) Integrating Africa's Least Developed Countries into the Global Carbon Market, Wuppertal / Hamburg. Available at: https://www.bmu. de/fileadmin/Daten_BMU/Pools/Forschungsdatenbank/CDM_African_LDCs_ english_bf.pdf. Accessed 22 Oct 2018.

Asmamaw LB, Mohammed AA, Lulseged TD (2011) Land use/cover dynamics and their effects in the Gerado catchment, northeastern Ethiopia. Int J Environ Stud 68:883-900

Assefa D, Rewald B, Sandén H, Rosinger C, Abiyu A, Yitaferu B, Godbold DL (2017) Deforestation and land use strongly effect soil organic carbon and nitrogen stock in Northwest Ethiopia. Catena 153:89-99

Aynekulu E, Vågen TG, Shephard K, Winowiecki L (2011) A protocol for modeling, measurement and monitoring soil carbon stocks in agricultural landscapes. Version 1.1. World Agroforestry Centre, Nairobi

Batjes NH (1996) Total carbon and nitrogen in the soils of the world. Eur J Soil Sci 47(2):151-163

Batjes NH (2001) Options for increasing carbon sequestration in West Africa soils: an exploratory study with special focus on Senegal. Land Degrad Dev 12:131-142

Batjes NH (2011) Research needs for monitoring, reporting and verifying soil carbon benefits in sustainable land management and GHG mitigation project. In: De Brogniez D, Montaraella L (eds) Monitoring, reporting and verification systems for carbon in soils and vegetation in African, Caribbean and Pacific Countries. European Commission Joint Research Center, Brussels, pp 27-39

Bazezew MN, Teshome S, Eyale B (2015) Above- and below-ground reserved carbon in Danaba community forest of Oromia region, Ethiopia: implications for $\mathrm{CO}_{2}$ emission balance. Am J Environ Prot 4(2):75-82

Belay B, Pötzelsberger E, Sisay K, Assefa D, Hasenauer H (2018) The carbon dynamics of dry tropical Afromontane forest ecosystems in the Amhara region of Ethiopia. Forests 9:18. https://doi.org/10.3390/f9010018

Berihu T, Girmay G, Sebhatleab M, Berhane E, Zenebe A, Sigua GC (2017) Soil carbon and nitrogen losses following deforestation in Ethiopia. Agron Sustain Dev 37:1

Birhane E, Ashfare H, Fenta AA, Hishe H, Gebremedhin MA, Wahed HG, Solomon N (2019) Land use land cover changes along topographic gradients in Hugumburda national forest priority area, northern Ethiopia. Remote Sens Appl: Soc Environm 13:61-68

Boke S (2014) Effect of organic and inorganic fertilizer application and seedbed preparation on potato yield and soil properties on Alisols of Chencha. Int J Nat Sci Res 2(8):123-132 
Bongers F, Wassie A, Sterck F, Bekele T, Teketay D (2006). Ecological restoration and church forests in northern ethiopia. J. Drylands 1:35-45.

Bureau of Planning and Economic Development (BoPED) (1995) Five years development plan of the Tigray region. Bureau of Planning and Economic Development, Mekelle

Cardelús C, Baimas-George M, Lowman M, Eshete AW (2013b) Church Forest status and carbon sequestration in northern Ethiopia. In: Lowman M, Dew S, Ganesh T (eds) Treetops at risk. Springer, New York https://doi.org/10.1007/978-1-4614-7161-5_11

Cardelús CL, Scull P, Hair J, Baimas-George M, Lowman MD, Eshete AW (2013a) A preliminary assessment of Ethiopian sacred grove status at the landscape and ecosystem scales. Diversity 5:320-334

Chabbi A, Rumpel C (2009) Guest editor's introduction. Organic matter dynamics in agro-ecosystems - the knowledge gaps) Eur J Soil Sci 60:153-157

Chatterjee A, Lal R, Wielopolski L, Martin MZ, Ebinger MH (2009) Evaluation of different soil carbon determination methods. Crit Rev Plant Sci 28:164-178

Chibsa T, Ta AA (2009) Assessment of soil organic matter under four land use systems in major soils of bale highlands, southeast Ethiopia (b) factors affecting soil organic matter distribution. World Appl Sci J 6(11):1506-1512 idosi.org/wasj/wasj6(11)/8.pdf

Corral-Nuñez G, Opazo-Salazar D, Gebresamuel G, Tittonell P, Gebretsadik A, Gebremeskel Y, Tesfay G, Beek CL (2014) Soil organic matter in northern Ethiopia, current level and predicted trend: a study case of two villages in Tigray. Soil Use Manag 30:487-495

Demessie A, Singh BR, Lal R (2011) Soil carbon and nitrogen stocks under plantations in Gambo District, southern Ethiopia. J Sust For 30:496-517

Demessie A, Singh BR, Lal R (2015) Land degradation and soil carbon pool in different land uses and their implication for food security in southern Ethiopia. In: Lal et al (eds) Sustainable intensification to advance food security and enhance climate resilience in Africa. Springer International Publishing Switzerland. https://doi.org/10.1007/978-3-319-09360-4_3

Demessie A, Singh BR, Lal R, Børresen T (2012) Effects of eucalyptus and coniferous plantations on soil properties in Gambo District, southern Ethiopia. Acta Agric Scand Sect B Soil Plant Sci 62(5):455-466. https://doi.org/ 10.1080/09064710.2011.644575

Demissie F, Yeshitila K, Kindu M, Schneider T (2017) Land use/land cover changes and their causes in Libokemkem District of south Gonder, Ethiopia. Remote Sens Appl Soc Environ 8:224-230

Descheemaeker K, Nyssen J, Poesen J, Haile M, Muys B, Raes D, Moeyersons J, Deckers J (2006a) Soil and water conservation through forest restoration in exclosures of the Tigray highlands. J Drylands 1(2):118-133

Descheemaeker K, Nyssen J, Rossi J, Poesen J, Haile M, Raes D, Muys B, Moeyersons J, Deckers S (2006b) Sediment deposition and pedogenesis in exclosures in the Tigray highlands, Ethiopia. Geoderma 132:291-314

Edwards S (2007) Role of organic agriculture in preventing and reversing land degradation, pp 523-536. In: Sivakumar MVK, Sivakumar VK, Ndiang'ui N (eds) Climate and land degradation. Springer, Berlin, p 623

Eshete AW (2007) Ethiopian church forests: opportunities and challenges for restoration. PhD thesis, Wageningen Univeristy, Wageningen ISBN: 978-90-8504-768-1

FAO (1986) Ethiopian highlands reclamation study (EHRS). Final reports, Vol 1-2. Food and Agriculture Organization, Rome

FAO (2001) Soil carbon sequestration for improved land management. World soil resources reports. Food and Agriculture Organization of the United Nations, Rome

FAO (2007) Impact of compost use on crop yields in Tigray, Ethiopia, report by Edwards S, Asmelash A, Araya H and Gebre Egziabher T., to Natural Resources Management and Envt Department, FAO (Food and Agriculture Organization), December 2007, Rome, Italy

Federal Democratic Republic of Ethiopia (2015) Ethiopia's Second National Communication to the United Nations Framework Convention on Climate Change (UNFCCC). Available at: http://unfccc.int/resource/docs/natc/ethnc2.pdf

Fisseha I, Mats O, Karl S (2011) Effect of land use changes on soil carbon status of some soil types in the Ethiopian rift valley. J Drylands 4(1):289-299

Fitsum H, Pender J, Nega G (1999) Land degradation in the highlands of Tigray and strategies for sustainable land management. In: Socio-economic and policy research paper No. 25

Foresight (2011). The Future of Food and Farming. Final Project Report. (The Government Office for Science, London). http://www.bis.gov.uk/foresight/ our-work/projects/current-projects/global-food-and-farming-futures/reportsand-publications.

Freier KP, Glaser B, Zech W (2009) Mathematical modeling of soil carbon turnover in natural Podocarpus forest and Eucalyptus plantation in Ethiopia using compound specific $813 C$ analysis. Glob Chang Biol 16(5):1487-1502
Gebeyehu G, Soromessa T, Teketay D (2017) Organic carbon stocks, dynamics and restoration in relation to soils of agroecosystems in Ethiopia: a review. Int J Environ 6(1):1-22

Gebremariam M, Kebede F (2010) Land use change effect on soil carbon stock, above ground biomass, aggregate stability and soil crust: A Case from Tahtay Adyabo, North Western Tigray, Northern Ethiopia. J Drylands 3 (2): 220-225.

Gebremedhin H, Gebresamual G, Abadi N, Hailemariam M, Teka K, Mesfin S (2018). Conversion of communal grazing land into arable land and its impacts on soil properties and vegetation cover. Arid Land Res Manage 32 (2): 236-252, DOl:10.1080/15324982.2017.1406412.

Gebreyesus B, Lulseged T, Paul LG (2014) Soil erosion prediction using MorganMorgan-Finney model in a GIS environment in northern Ethiopia catchment. Appl Environ Soil Sci. https://doi.org/10.1155/2014/468751

Gelaw AM, Singh BR, Lal R (2013) Organic carbon and nitrogen associated with soil aggregates and particle sizes under different land uses in Tigray, northern Ethiopia. Land Deg Devel. Published online in Wiley Online Library (wileyonlinelibrary.com). https://doi.org/10.1002//dr.2261

Gelaw AM, Singh BR, Lal R (2014) Soil organic carbon and total nitrogen stocks under different land uses in a semi-arid watershed in Tigray, northern Ethiopia. Agric Ecosyst Environ 188:256-263

Gelaw AM, Singh BR, Lal R (2015a) Land use impact on soil organic and total nitrogen storage in a typical dry land in Tigray, northern Ethiopia. In: Lal R et al (eds) Sustainable intensification to advance food security and enhance climate resilience in Africa. https://doi.org/10.1007/978-3-319-09360-4_4

Gelaw AM, Singh BR, Lal R (2015) Soil quality indices for evaluating smallholder 1577 agricultural land uses in northern Ethiopia. Sustainability 7:2322-2337

Gelman F, Binstock R, Halicz L (2012) Application of the Walkley-Black titration for the organic carbon quantification in organic rich sedimentary rocks. Fuel 96:608-610

Gessesse TA, Khamzina A (2018) How reliable is the Walkley-Black method for analyzing carbon-poor semi-arid soils in Ethiopia? J Arid Environ 153:98-101

Girmay G, Singh BR (2012) Changes in soil organic carbon stocks and soil quality: land-use system effects in northern Ethiopia. Acta Agric Scand Sect B Soil Plant Sci 62(6):519-530

Girmay G, Singh BR, Mitiku H, Borresen T, Lal R (2008) Carbon stocks in Ethiopian soils in relation to land use and soil management. Land Degrad Dev 19(4): $351-367$

Gonzalo J, Zewdie S, Tenkir E, Moges Y (2017) REDD+ and carbon markets: the Ethiopian process. In: Bravo F, LeMay V, Jandl R (eds) Managing forest ecosystems: the challenge of climate change. Managing forest ecosystems, vol 34. Springer, Cham

Grainger A (1995) The forest transition: an alternative approach. Area 27(3):242-251

Guo LB, Gifford RM (2002) Soil carbon stocks and land use change. Glob Chang Biol 8:345-360

Haile G, Lemenhi M, Itanna F, Senbeta F (2014) Impacts of land use changes on soil fertility, carbon and nitrogen stock under smallholder farmers in central highlands of Ethiopia: implication for sustainable agricultural landscape management around Butajira area. N Y Sci J 7(2):27-44

Hailemariam S, Soromessa T, Teketay D (2016) Land use and land cover change in the bale mountain eco-region of Ethiopia during 1985 to 2015. Land 5:41

Haileslassie A, Priess J, Veldkamp E, Teketay D, Lesschen JP (2005) Assessment of soil nutrient depletion and its spatial variability on smallholders' mixed farming systems in Ethiopia using partial versus full nutrient balances. Agric Ecosyst Environ 108:1-16

Haileslassie AJ, Priess A, Veldkamp E, Lesschenm JP (2006) Smallholders' soil fertility management in the central highlands of Ethiopia: implications for nutrient stocks, balances and sustainability of agroecosystems. Nutr Cycl Agroecosyst 75:135-146

Hailu AT (2010) The effect of compost on soil fertility enhancement and yield increment under smallholder farming — a case of Tahtai Maichew district Tigray Region, Ethiopia. PhD Thesis, Institute of Soil Science and Land Evaluation Faculty of Agricultural Sciences, University of Hohenheim, Germany

Hassink J (1997) The capacity of soils to preserve organic C and N by their association with clay and silt particles. Plant Soil 191:77-87

Hawando T (1997) Desertification in Ethiopian highlands, RALA report no 200. Norwegian Church AID, Addis Ababa.

Hooker BA, Morris TF, Peters R, Cardon ZG (2005) Long-term effects of tillage and corn stalk return on soil carbon dynamics. Soil Sci Soc America J 69:188-196

Hurni H, Amare B, Herweg K, Portner B, Veit H (eds) (2007) Landscape transformation and sustainable development in Ethiopia. Background information for a study tour through Ethiopia, September 4-20, 2006. CDE (Center for Development and Environment) University of Bern, Bern, p 321 
IPCC (2007) Climate change: the physical science basis. Contribution of working group I to the fourth assessment. In: Solomon S, Quin D, Manning M (eds) Report of the Intergovernmental Panel on Climate Change. Cambridge University Press, Cambridge

IPCC (2012) Glossary of terms. In: Field CB, Barros V, Stocker TF, Qin D, Dokken DJ, Ebi KL, Mastrandrea MD, Mach KJ, Plattner GK, Allen SK, Tignor M, Midgley PM (eds) Managing the risks of extreme events and disasters to advance climate change adaptation, A special report of working groups I and II of the intergovernmental panel on climate change (IPCC). Cambridge University Press, Cambridge and New York, pp 555-564

Israel T (2011) Soil Erosion risk assessment with RUSLE and GIS in dire dam watershed. Master's Thesis, Addis Ababa University, Addis Ababa

Itanna F, Olsson M, Stahr K (2011). Effect of Land Use Changes on Soil Carbon Status of Some Soil Types in the Ethiopian Rift Valley. Journal of the Drylands 4(1): 289-299.

Janik LJ, Skjemstad JO, Shepherd KD, Spouncer RL (2007) The prediction of soil carbon fractions using mid-infrared-partial least square analysis. Austral J Soil Res 45:73-81

Janzen HH, Campbell CA, Gregorich EG, Ellert BH (1998) Soil carbon dynamics in Canadian agroecosystems. In: Lal R, Kimle JM, Follett RF, Stewart BA (eds) Soil processes and the carbon cycle. CRC Press, Boca Raton, pp 57-80

Jiang JH, Zhang L, Wang XY, Holm N, Rajagopalan K, Chen FL, Ma S (2013). Highly ordered macroporous woody biochar with ultra-high carbon content as supercapacitor electrodes. Electrochim. Acta., 113: 481-489. https://doi. org/10.1016/j.electacta.2013.09.121.

Jobbagy EG, Jackson RB (2000) The vertical distribution of soil organic carbon and its relation to climate and vegetation. Ecol Appl 10:423-436

Kahsay A, Haile M, Gebresamuel G, Mohammed M (2018) Land suitability analysis for sorghum crop production in northern semi-arid Ethiopia: application of GIS-based fuzzy AHP approach. Cogent Food Agric 4(1):1-24

Kassa H, Dondeyne S, Poesen J, Frankl A, and Nyssen, Jan. (2017). Impact of deforestation on soil fertility, soil carbon and nitrogen stocks the case of the Gacheb catchment in the White Nile Basin, Ethiopia. Agriculture, Ecosystems and Environment 247: 273-282.

Kassahun HT, Lee DR, Nicholson CF, Poe GR, Collick AS, Steenhusis TS (2009) Payment for environmental service to enhance environmental productivity in the Blue Nile Basin. International water management institute (IWMI), poster presented for upstream-downstream meeting of the Blue Nile Basin, February 5-6, Addis Ababa, Ethiopia

Kim DG, Terefe B, Girma S, Kedir H, Morkie N, Woldie TM (2015) Conversion of home garden agroforestry to crop fields reduced soil carbon and nitrogen stocks in southern Ethiopia. Agrofor Syst. https://doi.org/10.1007/s1045710015-19851-10455

Kindu M, Schneider T, Teketay D, Knoke T (2013) Land use/land cover change analysis using object-based classification approach in Munessa-Shashemene landscape of the Ethiopian highlands. Remote Sens 5:2411

Kirschbaum MUF (2000). Will changes in soil organic carbon act as a positive or negative feedback on global warming? Biogeochemistry 48: 21-51.

Krull ES, Baldock J, Skjemstad J (2003) Importance of mechanisms and processes of the stabilization of soil organic matter for modeling carbon turnover. Funct Plant Biol 30:207-222

Lal R, Kimble JM, Follett RF, Cole CV (1998). The Potential of U.S. Cropland to Sequester Carbon and Mitigate the Greenhouse Effect. Chelsea, MI.

Lal R (2001) Potential of desertification control to sequester carbon and mitigate the greenhouse effect. Clim Chang 51:35-72

Lal R (2002) Carbon sequestration in dry land ecosystems of West Asia and North Africa. Land Degrad Dev 13:45-59

Lal R (2004a) Soil carbon sequestration impacts on global climate change and food security. Science 304:1623-1627

Lal R (2004b) Soil carbon sequestration to mitigate climate change. Geoderma 123:1-22

Lal R (2008c) Sequestration of atmospheric $\mathrm{CO}_{2}$ in global carbon pools. Energy Environ Sci 1(1):86-100

Lal R (2008a) Carbon sequestration. Philos Trans R Soc 363:815-830

Lal R (2008b) Soil carbon stocks under present and future climate with specific reference to European ecoregions. Nutr Cycl Agroecosyst 81:113-127

Lal R (2015a) Sequestering carbon and increasing productivity by conservation agriculture. J Soil Water Conserv 70:55A-62A

Lal R (2015b) A system approach to conservation agriculture. J Soil Water Conserv 70:5A-60A

Lal R (2016) Biochar and Soil Carbon Sequestration. In: Guo M, He Z, Uchimiya SM (eds) @ SSSA, 5585 Guilford Rd., Madison, WI 53711, USAAgricultural and environmental applications of biochar: advances and barriers. SSSA Special Publication 63. https://doi.org/10.2136/sssaspecpub63.2014.0042.5

Lal R, Lorenz K, Huttle RF, Schneider BU, Von Braun J (2012) Terrestrial biosphere as a source and sink of atmospheric carbon dioxide. In: Lal et al (eds) Recarbonization of the biosphere: Ecosyst global cycle. https://doi.org/10. 1007/978-94-007-4159-1_1

Landon JR (ed) (1991) Booker tropical soil manual: a handbook for soil survey and agricultural land evaluation in the tropics and subtropics. Booker Tate Limited, London

Lemenih M, Itanna F (2004) Soil carbon stocks and turnovers in various vegetation types and arable lands along an elevation gradient in southern Ethiopia. Geoderma 123(1and2):177-188

Lemenih M, Lemma B, Teketay D (2005) Changes in soil carbon and total nitrogen following reforestation of previously cultivated land in the highlands of Ethiopia. Ethiopian J Sci 28(2):99-108

Lemma B, Kleja DB, Nilsson I, Olsson M (2006) Soil carbon sequestration under different exotic tree species in the southwestern highlands of Ethiopia. Geoderma 136:886-898

Loveland P, Webb J (2003) Is there a critical level of organic matter in the agricultural soils of temperate regions: a review. Soil Tillage Res 70:1-18

Luo Z, Wang E, Sun OJ (2010) Soil carbon change and its responses to agricultural practices in Australian agro-ecosystems: a review and synthesis. Geoderma 155:211-223

Marland G, Obersteiner M, Schlamadinger B (2007) The carbon benefits of fuels and forests. Science 318(5853):1066-1068

Matovic D (2011). Biochar as a viable carbon sequestration option: Global and Canadian perspective. Energy 36: 2011-2016. doi:10.1016/j.energy.2010.09.031.

Mbah CN, Njoku C, Okolo CC, Attoe E, Osakwe UC (2017) Amelioration of a degraded Ultisol with hardwood biochar: effects on soil physicochemical properties and yield of cucumber (Cucumis sativus L). Afr J Agric Res 12(21):1781-1792

Mekonnen D (2006). Effects Of Integrated Nutrient Management On Agronomic Performance of Potato (Solanum Tuberosum. L. ) and Fertility of Nitosol at Bako. Unpublished MSc Thesis submitted to the Department of Plant Science, School of Graduate Studies, Alemaya University Ethiopia in partial fulfillment of the requirements for the Degree of Master of Science in Agriculture (Horticulture).

Mekuria W (2010) Effectiveness of exclosures to restore ecosystem carbon stock and vegetation in the highlands of Tigray, northern Ethiopia. J Arid Environ 69:270-284

Mekuria W (2013) Changes in regulating ecosystem services following establishing exclosures on communal grazing lands in Ethiopia: a synthesis. J Ecosystems https://doi.org/10.1155/2013/860736

Mekuria W, Aynekulu E (2013) Exclosure land management for restoration of the soils in degraded communal grazing lands in northern Ethiopia. Land Degrad Dev 24:528-538

Mekuria W, Noble A (2013) The role of biochar in ameliorating disturbed soils and sequestering soil carbon in tropical agricultural production systems. Appl Environ Soil Sci. https://doi.org/10.1155/2013/354965

Mekuria W, Veldkampa E, Haile M (2009) Carbon stock changes with relation to land use conversion in the lowlands of Tigray, Ethiopia. Conference on International Research on Food Security, Natural Resource Management and Rural Development. Tropentag 2009 University of Hamburg, October 6-8, 2009

Mekuria W, Yami M (2013). Changes in woody species composition following establishing exclosures on grazing lands in the lowlands of northern Ethiopia. Afr J Environ Sci Technol 7(1):30-40

Mellerowicz K, Ress H, Chow T, Ghanem I (1994) Soil conservation planning at the watershed level using the universal soil loss equation with GIS and microcomputer technologies: a case study. J Soil Water Conserv 49:194-200

Mesfin A (1988) The nature and management of Ethiopian soils. Alemaya University of Agriculture (AUA), Ethiopia, p 272

Michelsen A, Andersson M, Jensen M, Kjøller A, Gashew M (2004) Carbon stocks, soil respiration and microbial biomass in fire-prone tropical grassland, woodland and forest ecosystems. Soil Biol Biochem 36:1707-1717.

Miheretu BA, Abegaz A (2017) Spatial variability of selected soil properties in relation to land use and slope position in Gelana sub-watershed, Northern highlands of Ethiopia. Phys Geogr. https://doi.org/10.1080/ 02723646.2017 .1380972

Mitiku H, Kindeya G (1998) Efforts to rehabilitate degraded lands: local initiatives for planning resource management in Tigray northern Tigray. Sustainable development of dry land areas of East Africa, Proceedings of the international workshop. European commission, Addis Ababa, pp 319-328

Mohammed G, Bekele M (2014) Changes in carbon stocks and sequestration potential under native Forest and adjacent land use systems at Gera, southwestern Ethiopia. Global J Sci Front Res 14(10):1-11 
Mulugetta Y (2011). Climate change and carbon trading in Africa. In: Reddy $T$ (ed) Carbon trading in Africa: a critical review. Institute for Security Studies, Cape Town

Negasa T, Ketema H, Legesse A, Sisay M, Temesgen H (2017) Variation in soil properties under different land use types managed by smallholder farmers along the toposequence in southern Ethiopia. Geoderma 290:40-50

Negash M, Starr M (2015). Biomass and soil carbon stocks of indigenous agroforestry systems on the south-eastern Rift Valley escarpment, Ethiopia. Plant Soil. https://doi.org/10.1007/s11104-015-2469-6

Nigussie A, Kissi E, Misganaw M, Ambaw G (2012) Effect of biochar application on soil properties and nutrient uptake of lettuces (Lactuca sativa) grown in chromium polluted soils. American-Eur J Agric Environ Sci 12:369-376

Niles JO, Cleland E, Gibbs H, Orcutt B (2010) Carbon finance in Ethiopian rangelands: opportunities for save the children leadership, final TFG report submitted to save the children, Addis Ababa, Ethiopia

NMSA (2001) Initial national communication of Ethiopia to the United Nations framework convention on climate change (UNFCCC). National Meteorological Services Agency (NMSA, Addis Ababa

Nwite JN, Okolo CC (2017) Organic carbon dynamics and changes in some physical properties of soil and their effect on grain yield of maize under conservative tillage practices in Abakaliki, Nigeria. Afr J Agric Res 12:2215-2222

Nyssen J, Frankl A, Zenebe A, Deckers J, Poesen J (2015) Land management in the northern Ethiopian highlands: local and global perspectives; past, present and future. Published online in Wiley online library (wileyonlinelibrary.com). https://doi.org/10.1002/ldr.2336

Nyssen J, Munro N, Haile M, Poesen J, Descheemaeker K, Haregeweyn N, Decker $J$ (2007) Understanding the environmental changes in Tigray: a photographic record over 30 years. Tigray Livelihood Papers 3:82

Okebalama CB, Igwe CA, Okolo CC (2017) Soil organic carbon levels in soils of contrasting land uses in southeastern Nigeria. Trop Subtrop Agroecosyst 20:493-504

Okolo CC, Raj AJ, Gidey K (2016) Soil carbon sequestration as a veritable tool for building resilience to climate change in Ethiopia: a review. In: Girmay et al (eds) Proceedings of the International Conference on Improving Food Security in the Face of Climate of Change held at Axum hotel, Mekelle, Ethiopia, 13-15 July 2015. Published by Institute of Climate and Society, Mekelle University, Ethiopia, pp 182-184

Patrick M, Tenywa JS, Ebanyat P, Tenywa MM, Mubiru DN, Basamba TA, Leip A (2013) Soil organic carbon thresholds and nitrogen management in tropical agroecosystems: concepts and prospects. J Sust Dev 6(12):31-43

Post WM, Amonette XJ, Birdsey R, Garten CT Jr, Izaurralde RC, Jardine PM, Jastrow J, La R, Marland G, McCarl BA, Thompson AM, West TO, Wullschleger SD, Metting FB (2009) Terrestrial biological carbon sequestration: science for enhancement and implementation. In: McPherson BJ, Sundquist EJ (eds) Carbon sequestration and its role in the global carbon cycle. Geophysical monograph series 183. American Geophysical Union, Washington, D. C, pp 73-88

Post WM, zaumalde RC, Jastrow JD, McCarl BA, Amonette JE, Bailey V, Jardine PM, Tristram OW, Zhou J (2004) Enhancement of carbon sequestration in US soils. Bioscience 54:895-908

Post WM, Kwon KC (2000) Soil carbon sequestration and land-use change: processes and potential. Glob Chang Biol 6:317-327

Powlson DS, Riche AB, Coleman K, Glendining MJ, Whitmore AP (2008) Carbon sequestration in European soils through straw incorporation: limitations and alternatives. Waste Manag 28:741-746

Powlson DS, Whitmore AP, Goulding KWT (2011) Soil carbon sequestration to mitigate climate change: a critical re-examination to identify the true and the false. Eur J Soil Sci 62:42-55

Reda AG (2015) The contribution of soil and water conservation practices towards sustainable rural livelihoods in Tigray region, northern Ethiopia. Unpublished PhD dissertation (specialization in natural resource management and environment), Department of Geography and Environmental Studies, Addis Ababa university, Ethiopia

Robert M (2006) Global change and carbon cycle: the position of soil and agriculture. In: Erosion and carbon dynamics. Tailor and Francis Group, London, pp 3-12

Ruddiman WF (2003). The anthropogenic greenhouse era began thousands of years ago. Climate Change 61: 261-293.

Shiferaw A, Hans H, Gete Z (2013) A review on soil carbon sequestration in Ethiopia to mitigate land degradation and climate change. J Environ Earth Sci 3(12):187-201

Shiferaw A, Hergarten C, Tibebu K, Zeleke G (2015). Meta-Analysis of long-term management effect on soil organic carbon in Ethiopia. International Journal of Agricultural Research 10 (1): 1-13. DOI: 10.3923/ijar.2015.1.13.
Singh BR, Wele AD, Lal R (2010) 19th World Congress of Soil Science, Soi Solutions for a Changing World 1-6 August 2010, Brisbane, Australia. Published on DVD

Smith P (2008) Land use change and soil organic carbon dynamics. Nutr Cycl Agroecosyst 81:169-178

Sohi S, Lopez-Capel E, Krul El, Bol R. (2009) "Biochar, climate change and soil: a review to guide future research," CSIRO Land and Water Science Report 05/ 09, CSIRO, Highett, Australia

Sohi SP, Krull E, Lopez-Cappel E, Bol R (2010) A review of biochar and its use and function in soil. Adv Agron 105:47-82

Solomon D, Fritzsche F, Lehmann J, Tekalign M, Zech W (2002b) Soil organic matter dynamics in the sub-humid agroecosystems of the Ethiopian highlands: evidence from natural $\mathrm{C}$ abundance and particle-size fractionation. Soil Sci Soc America J 66:969-978

Solomon D, Fritzsche F, Tekalign M, Lehmann J, Zech W (2002a) Soil organic matter composition in the sub humid Ethiopian highlands as influenced by deforestation and agricultural management. Soil Sci Soc America J 66:68-82

Squire VR, Glenn EP, Ayoub AT (eds) (1995) Combating global climate change by combating land degradation. UNEP, Nairobi, p 347

SSSA (2001) Carbon sequestration in soils: position of the Soil Science Society of America. Soil Science Society of America (SSSA) Ad Hoc Committee 5893 Report, USA

Steiner C (2010). Biochar in agricultural and forestry applications, in Biochar from Agricultural and Forestry Residues-a Complimentary Use of "Waste" Biomass. Assessment of Biochar's Benefits for the United States of America, US Biochar Initiative, 2010.

Stockmann U, Adams MA, Crawford JW, Field DJ, Henakaarchchi MJ, Minasny B, McBratney AB, de Courcelles VDR, Singh K, Wheeler I, Abbott L, Angers DA, Baldock J, Bird M, Brookes PC, Chenu C, Jastrow JD, Lal R, Lehmann J, O'Donnel AG, Parton WJ, Whitehead D, Zimmerman M (2013) The knowns, known unknowns and unknowns of sequestration of soil organic carbon. Agric Ecosyst Environ 164:80-99

Tieszen LL (2000). Carbon Sequestration in semi-arid and sub-humid Africa. U.S Geological Survey, EROS Data Center, Sioux Falls, South Dakota. http:// edcintl.cr.usgs.gov/ip.

Tura TT, Eshetu Z (2013) Estimation of carbon stock in church forests: implications for managing church Forest to help with carbon emission reduction. Chapter In Book: Climate-Smart Technologies January 2013. https://doi.org/10.1007/978-3-642-37753-2_30

Ubuy MH, Gebrehiwot K, Raj AJ (2014) Biomass estimation of exclosure in the Debrekidan watershed, Tigray region, northern Ethiopia. Int J Agric For 4(2):88-93

UNFCCC (2002) United Nations framework convention on climate change: a guide to the climate change convention process. Preliminary $2^{\text {nd }}$ edition. Climate Change Secretariat Bonn, Germany

USGS (2008) US geological survey. Carbon sequestration to mitigate climate change. Fact Sheet 2008-3097. December, 2008

Vågen TG, Davey F, Shepherd KD (2012). Land health surveillance: mapping soil carbon in Kenyan rangelands. In: Nair PKR, Garrity D (eds) Agroforestry - the future of global land use (Advances in agroforestry). Springer, New York, p 455-462.

Vågen TG, Lal R, Singh BR (2005) Soil carbon sequestration in sub-Saharan Africa: a review. Land Degrad Dev 16:53-71

Vågen TG, Winowiecki LA, Abegaz A, Hadgu KM (2013) Landsat-based approaches for mapping of land degradation prevalence and soil functional properties in Ethiopia. Remote Sens Environ 134:266-275

Verheijen FGA, Jefferey S, Bastos AC, van der Velde M, Diafas I (2009) Biochar application to soils - a critical scientific review of effects on soil properties, processes and functions. EUR 24099 EN. Office for the Official Publications of the European Communities, Luxembourg

Walkley A, Black I (1934) An examination of methods for determining soil organic matter and a proposed modification of the chromic acid titration method. Soil Sci 79:459-465

Wang X, Wang J, Zhang J (2012) Comparisons of three methods for organic and inorganic carbon in calcareous soils of north-western China. PLoS One 7:e44334

Warra HH, Ahmed MA, Nicolau M (2015) Impact of land cover changes and topography on soil quality in the Kasso catchment, Bale Mountains of southeastern Ethiopia. Singap J Trop Geogr 36(3). https://doi.org/10.1111/ sjtg. 12124

Wassie A (2002) Opportunities and prospects of the Ethiopian orthodox Tewahido churches in conserving Forest resources: the case of churches in 
South Gondar, northern Ethiopia. M.Sc. thesis. Swedish University of Agriculture, Uppsala

Wassie A, Sterck FJ, Teketay D, Bongers F (2009) Tree regeneration in church forests of Ethiopia: effects of microsites and management. Biotropica 41(1):110-119

Wassie A, Teketay D (2006) Soil seed banks in church forests of northern Ethiopia: implications for the conservation of woody plants. Flora 201:32-43

Welemariam M, Kebede F, Bedadi B, Birhane E (2018) Exclosures backed up with community-based soil and water conservation practices increased soil organic carbon stock and microbial biomass carbon distribution, in the northern highlands of Ethiopia. Chem Biol Technol Agric 5:12

WMO (2010) Greenhouse bulletin: the state of the greenhouse gases in the atmosphere based on observations through 2009, Geneva, Switzerland

Wolde M, Veldkamp E (2005) Impact of land use changes on soil nutrients and erosion in Tigray, Ethiopia. A paper presented on International conference on Agricultural and Research for Development. October 11-13, 2005, StuttgartHohenheim, Germany

Woldemariam GW, Iguala AD, Tekalign S, Reddy RU (2018) Spatial modeling of soil erosion risk and its implication for conservation planning: the case of the Gobele watershed, east Hararghe zone, Ethiopia. Land 7:25

Woo SH (2013). Biochar for Soil Carbon Sequestration. Clean Tech., 19(3): 201:211 [in Korean].

World Bank (2010) Kenya agricultural carbon project (English). World Bank, Washington, DC. http://documents.worldbank.org/curated/en/ 687891468047729548/Kenya-Agricultural-Carbon-Project

Worldometers (2018) http://www.worldometers.info/world-population/ethiopiapopulation/. Assessed 19 June 2018

WRB (2006) International Union of Soil Science Working Group. World Soil Resources Reports No. 103. FAO, Rome

Yayneshet T, Eik LO, Moe SR (2009) The effects of exclosures in restoring degraded semi-arid vegetation in communal grazing lands in northern Ethiopia. J Arid Environ 73(4-5):542-549

Yimer F, Ledin S, Abdelkadir A (2006) Soil organic carbon and nitrogen stocks as affected by topographic aspect and vegetation in the Bale mountains, Ethiopia. Geoderma 135:335-344

Yimer F, Ledin S, Abdelkadir A (2007) Changes in soil organic carbon and total nitrogen contents in three adjacent land use types in the Bale mountains, southeastern highlands of Ethiopia. For Ecol Manag 242(2-3):337-342

Yohannes H, Soromessa T (2019) Integration of remote sensing, GIS and MCDM for land capability classification in Andit Tid watershed, Ethiopia. J Indian Soc Remote Sens. https://doi.org/10.1007/s12524-019-00949-z

Yosef BA (2012) Carbon stock potentials of woodlands and land use and land cover changes in northwestern lowlands of Ethiopia. A thesis submitted to the School of Natural Resources and Environmental Studies, Wondo Genet College of Forestry and Natural Resources, Hawassa University, in partial fulfilment for the degree of Master of Science in Integrated Watershed Management

\section{Submit your manuscript to a SpringerOpen ${ }^{\circ}$ journal and benefit from:}

- Convenient online submission

- Rigorous peer review

- Open access: articles freely available online

High visibility within the field

- Retaining the copyright to your article

Submit your next manuscript at $\boldsymbol{\nabla}$ springeropen.com 